INTER NATIONAL MONETARY FUND
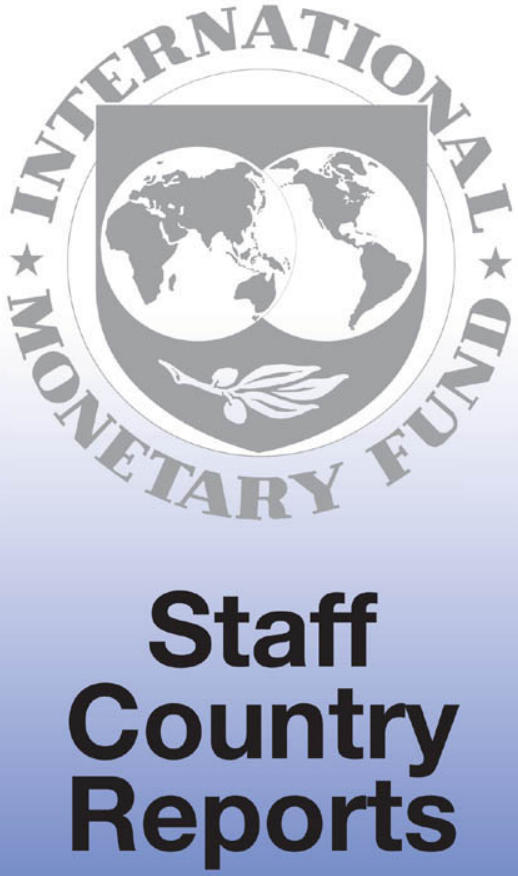


\section{Islamic Republic of Mauritania: Sixth Review Under the Poverty Reduction and Growth Facility and Request for Waiver of Performance Criterion-Staff Report; News Brief on the Executive Board Discussion; and Statement by the Executive Director for the Islamic Republic of Mauritania}

In the context of the sixth review under the Poverty Reduction and Growth Facility and request for waiver of performance criterion, the following documents have been released and are included in this package:

- the staff report for the sixth review under the Poverty Reduction and Growth Facility and request for waiver of performance criterion, prepared by a staff team of the IMF, following discussions that ended on September 27, 2002, with the officials of Mauritania on economic developments and policies. Based on information available at the time of these discussions, the staff report was completed on November 20,2002 . The views expressed in the staff report are those of the staff team and do not necessarily reflect the views of the Executive Board of the IMF,

- a News Brief summarizing the views of the Executive Board as expressed during its December 4, 2002 discussion of the staff report that completed the review.

- a statement by the Executive Director for the Islamic Republic of Mauritania.

The documents listed below have been or will be separately released.

Letter of Intent sent to the IMF by the authorities of the Islamic Republic of Mauritania*

*May also be included in Staff Report

The policy of publication of staff reports and other documents allows for the deletion of market-sensitive information.

To assist the IMF in evaluating the publication policy, reader comments are invited and may be sent by e-mail to publicationpolicy@imforg.

Copies of this report are available to the public from

International Monetary Fund - Pubicication Services

$70019^{\text {th }}$ Street, N.W. - Washington, D.C. 20431

Telephone: (202) 623-7430 - Telefax: (202) 623-7201

E-mail: publications@imf org • Internet: http:/www.imf.org

Price: $\$ 15.00$ a copy

International Monetary Fund

Washington, D.C. 
INTERNATIONAL MONETARY FUND

ISLAMIC REPUBLIC OF MAURITANIA

Sixth Review Under the Poverty Reduction
and Growth Facility Arrangement and
Request for Waiver of a Performance Criterion

Prepared by the Middle Eastern Department

(In consultation with other departments)

Approved by George T. Abed and Michael Hadjimichael

November 20, 2002

- A staff team visited Nouakchott from September 14-27, 2002 to conduct discussions for the sixth and last review under the Poverty Reduction and Growth Facility (PRGF) Arrangement. The current PRGF Arrangement expires on December 20, 2002.

- The team included Mr. Chami (head), Mr. Ben Ltaifa, Ms. Beidas, Mr. Carnot (all MED), and Mr. Jones (PDR). Mr. Youm, the Fund resident representative, assisted the mission. The team met with the governor of the central bank, the minister of finance, the minister of economic affairs and development, the head of the Agency for Human Rights, Fight Against Poverty and Integration (CDHLCPI), as well as with other senior officials.

- Shortly after this mission, the Managing Director, accompanied by Mr. Abed and Mr. Chami (MED), visited Mauritania on October 14-15 where he met the president, the prime minister, and other high-ranking government officials. The Managing Director congratulated the authorities on their strong performance under the PRGF Arrangement and on reaching the completion point under the enhanced HIPC Initiative and urged them to address the remaining weaknesses in the operation of the foreign exchange market, management of public expenditures, and the functioning of the banking system.

- In the attached letter of intent, the authorities request a waiver for the nonobservance of the performance criterion on the publication of the audit of the central bank for 2001, due to a delay in the preparation of the audit by the external auditor. The authorities have expressed an interest in a successor PRGF Arrangement.

- The fifth review under the PRGF Arrangement was completed on June 7, 2002. At that time, the Fund Board considered Mauritania's completion point document. The Board found that Mauritania reached its completion point on June 20, after the World Bank concluded that Mauritania had satisfactorily implemented its poverty reduction strategy for one year and had reached the completion point under the enhanced HIPC Initiative.

- The principal author of this report is Saade Chami. 


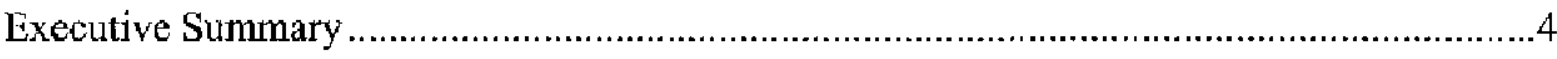

I. Performance Under the Program..........................................................................

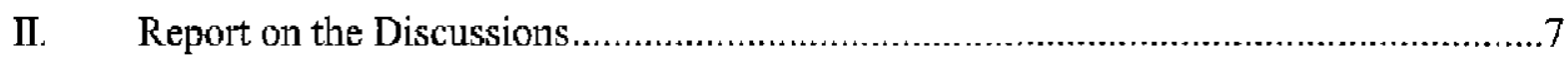

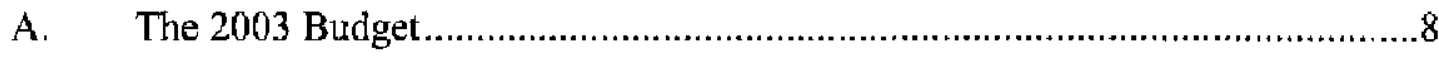

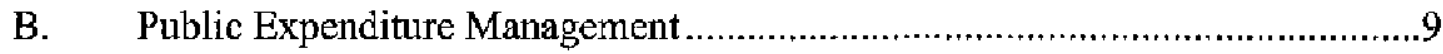

C. The Foreign Exchange Market.......................................................................11

D. Monetary Policy and Banking Sector Issues..................................................16

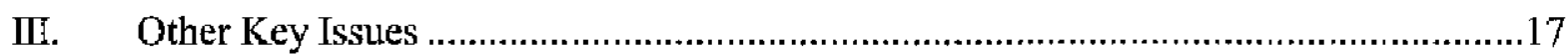

IV. Monitoring and Successor PRGF Arrangement.....................................................20

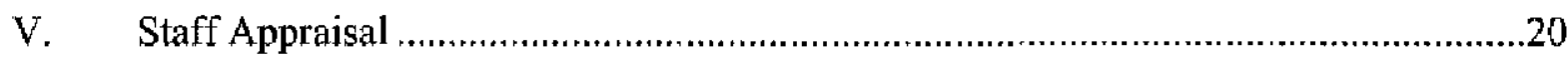

Text Boxes

1. The Reform of the Wage and Salary Tax....................................................................10

2. Implementation Status of Actions to Strengthen Tracking of

3. The Foreign Exchange Market............................................................................14

4. Transferring Government Deposits to the Central Bank ........................................18

$\underline{\text { Figure }}$

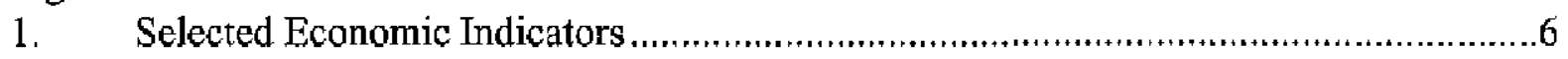

$\underline{\text { Tables }}$

1. Selected Economic and Financial Indicators, 1999-2003 ….................................23

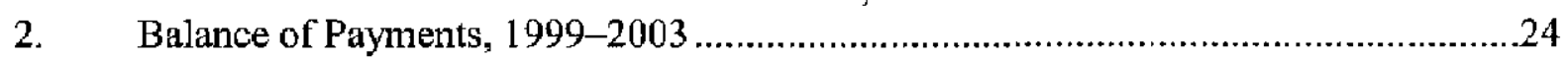

3. Consolidated Government Financial Operations, 2000-03 ..................................25

4. Summary Monetary Accounts, 2001-03 .......................................................27

5 . Performance Criteria and Structural Benchmarks for $2002 \ldots \ldots \ldots \ldots \ldots \ldots \ldots \ldots \ldots \ldots \ldots . .28$

6. Quarterly Quantitative Benchmarks and Performanee Criteria for $2002 \ldots \ldots \ldots \ldots \ldots \ldots . .29$

7. Macroeconomic Framework, 1999-2007 ............................................................30

8. The Change in Banking Prudential Indicators Between End-200l and End-June 2002 ….....................................................................................

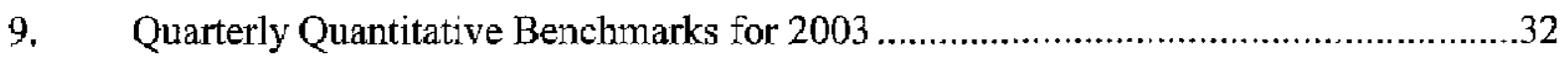


Appendices

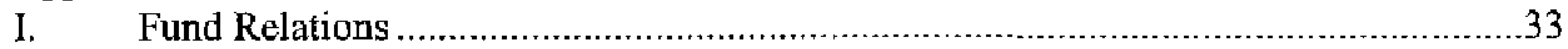

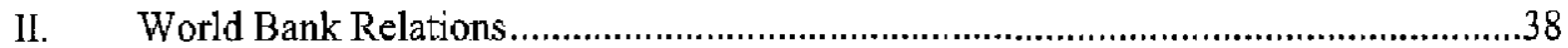

Attachment

Letter of Intent

42 


\section{EXECUTIVE SUMMARY}

\section{Background}

Performance under the program--Performance under the PRGF-supported program remained strong in 2002. All the quantitative and structural performance criteria and benchmarks were met except for the publication of the audit of the central bank accounts, which was delayed for technical reasons.

Macroeconomic performance - Growth is likely to be lower than programmed in 2002 by one percentage point (at 4.2 percent), on account of droughts and the drop in fish and iron ore exports. End-August inflation stood at 2.4 percent (year-on-year). The external current account is projected to improve despite the increase in the trade deficit, and international reserves should remain high at eight months of imports.

Macroeconomic policies - The overall fiscal position through June was better than expected on account of larger tax revenue, while expenditures were in line with the program-although the execution rate for social and poverty-related projects was low. Reflecting slower growth, credit to the private sector and broad money came in less than projected. Between January and July, the ouguiya depreciated significantly agairst the euro and less so against the U.S. dollar, with the real effective exchange rate depreciating by about 8 percent.

\section{Policy Issues}

The 2003 budget -Discussions on the 2003 budget focused on increasing social and poverty-related spending, maintaining good tax collection, and reforming the wage and salary tax. The latter consists of replacing the existing tax structure of 11 average rates ranging from 6 percent to 39 percent with a structure based on 2 marginal rates of 15 percent and 40 percent and a general exemption of UM 10,000 . Also, the authorities decided to reduce again the corporate income tax rate from 25 percent to 20 percent. Compensatory measures should limit the net loss of this reform to 0.3 percent of GDP.

Public expenditure management--A set of measures was agreed with the authorities to improve further public expenditure transparency and accountability. These include: (i) producing regularly monthly fiscal accounts (TOFE) beginning in January 2003; (ii) improving the tracking of public expenditures; (iii) computerizing the expenditure chain; and (iv) producing an overall medium-term expenditure framework by mid-2004.

The foreign exchange market-In light of the reported difficulties in obtaining foreign exchange from banks and the increased spread between the official and parallel rates, the central bank needs to (i) raise its intervention in the exchange market; (ii) ensure that banks do not limit the supply of foreign exchange to their groups or extended families; and (iii) provide signals to the market by announcing a daily opening buy/sell intervention rate and eliminating the practice of bidding "at best" price. Staff also recommended other measures aiming at improving the transparency and public understanding of the exchange market.

\section{Staff Appraisal}

The staff commends the authorities for bringing to a successful conclusion the current PRGF Arrangement and for their impressive record on macroeconomic stability and structural reforms. However, major challenges remain. Foremost among these is how to reduce and eventually eradicate poverty in the face of relatively limited resources while maintaining financial stability and external debt sustainability. The staff agrees with the orientations of fiscal policy in 2003 and the reform of the payroll tax and stresses the need to strengthen further public expenditure management and improve implementation capacity to accelerate the pace of secial spending. The staff considers that enhancing the functioning of the foreign exchange market is pivotal for private sector investment and growth. 


\section{Performance Under the Program}

\section{All indicators point to slower-than-programmed growth in 2002, but other} program objectives remain well within reach. A severe drought, a drop in fish catch, and a slightly lower mining production are likely to reduce the real growth rate from 5.1 percent under the program to 4.2 percent. ${ }^{1}$ Inflation remained subdued at 2.4 percent in August (yearon-year) with no apparent response to the sizable depreciation of the ouguiya against the euro or the U.S, dollar (Table 1 and Figure 1). ${ }^{2}$ The increase in the trade deficit on account of both lower exports and higher imports was more than offset by lower net service payments, resulting in a larger current account surplus. Gross official reserves reached US\$425 million in August (about nine months of imports) following the receipt of the European Union's 2002 fishing license payment ( $€ 86$ million) in July-against an end-year target of US\$372 million (Table 2).

\section{The overall budget surplus through June was larger than envisaged essentially} on account of higher revenues. ${ }^{3}$ At an estimated 4.3 percent of GDP, the overall budget surplus reflected mainly improved tax collections and better compliance following the reduction in the corporate tax rate from 35 percent to 25 percent in 2002 . Total expenditures were in line with the program, although the execution rate of social and poverty-related spending was lower than expected. The authorities allocated an additional UM 1 billion ( 0.4 percent of GDP) for the remainder of 2002 to respond to the needs of those who were hard-hit by the recent drought (Table 3).

3. Slower economic activity in the first half of the year was reflected in lower credit to the private sector and less expansionary monetary policy. Credit to the private sector was about 5 percent lower, while broad money was only marginally less than programmed. The interest rate on treasury bills was about 6.5 percent in August, maintaining a gap of over 4 percent with the repo rate, broadly in line with earlier understandings. There were sharp variations in the stock of treasury bills in the second quarter, perhaps reflecting the monetary authorities' attempt to keep monetary aggregates close to their programmed levels (Table 4).

\footnotetext{
${ }^{1}$ The decline in fish catch (and fish export) was reported to have been caused by migration of stocks due to cold water. This was confirmed by some foreign experts working in Mauritania.

${ }^{2}$ This is puzzling given the large size of imported goods in domestic demand, although this may reflect some weaknesses in the way the consumer price index, which is still limited to Nouakchott, is measured. In the past, inflation responded partially with a ligg of several months to exchange rate depreciation.

${ }^{3}$ The budget supplus in 2002 is due to the receipt of both the 2001 and 2002 fishing license payments by the European Union in 2002. Excluding the 2001 fishing license payment, the budget deficit would be at 1.2 percent of GDP.
} 
Figure 1: Mauritania: Selected Economic Indicators
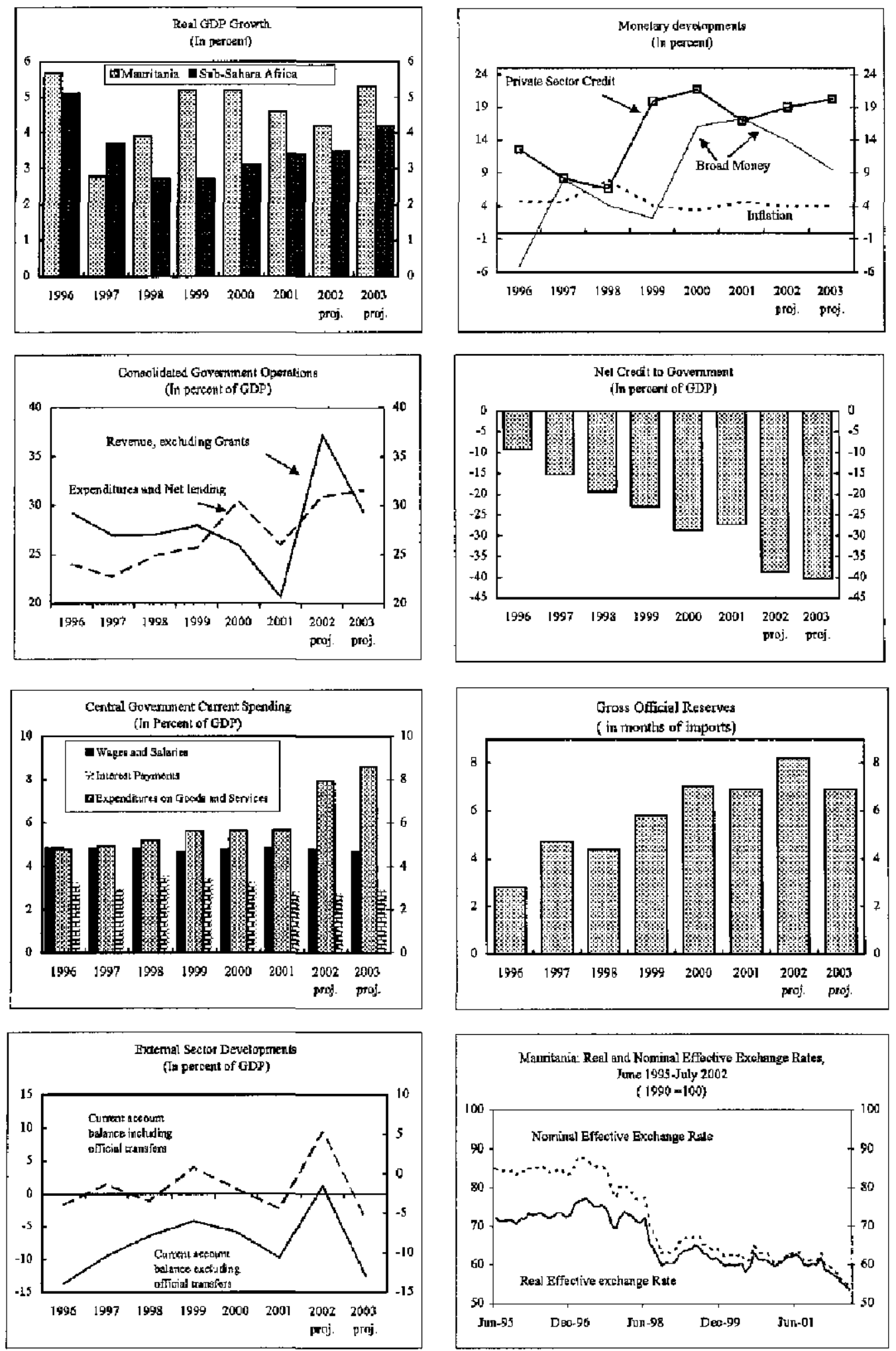

Sources: Mauritanian authorities; and Fund staff estimates. 
4. The modernization plan for customs reform is proceeding well. The

SYDONIA III was fully tested and, while it functions well in Nouakchott (where 75 percent of trade is recorded), it could not yet be implemented in other cities (Nouadhibou and Rosso) for lack of space to house the new equipment-this implementation is expected in the first half of next year. Legislation for customs valuation in accordance with WTO rules became effective in June 2002.

5. Some social indicators have improved recently. Regarding the unfulfilled social conditions for the HIPC completion point, the child vaccination rate reached 72 percent in June 2002 (exceeding the 70 percent target), and the secondary school enrollment and the $5^{\text {th }}$ grade retention rates increased to 24 percent and 57 percent in 2001 , compared to 20 percent and 55 percent in 2000 , respectively.

Mauritania: Poverty and Social Indicators, 1990-2002

\begin{tabular}{|c|c|c|c|c|c|}
\hline & 1990 & 1996 & 2002 & 2001 & 200211 \\
\hline & \multicolumn{5}{|c|}{ (Ith percent) } \\
\hline \multicolumn{6}{|l|}{ Poverty } \\
\hline Total population & & 51 & 46 & & \\
\hline \multicolumn{6}{|l|}{ Geographic distribution of poverty } \\
\hline Nouakchott & & 21 & 25 & & \\
\hline River-based rural & & 60 & 72 & & \\
\hline \multicolumn{6}{|l|}{ Education } \\
\hline Gross enrollment rate of primary education & 46 & 82 & 88 & & \\
\hline Share of girls in total primary enrollment & 42 & 46 & 49 & & \\
\hline Gross enrollment in lower secondary & 15 & 18 & 20 & 24 & \\
\hline Retention rate at entrance of the $5^{\text {th }}$ grade & & & 55 & 57 & \\
\hline \multicolumn{6}{|l|}{ Health } \\
\hline Child vaceination rate & & 30 & & & 72 \\
\hline HIV prevalence rate among blood donors & & 0.5 & & & 0.6 \\
\hline
\end{tabular}

1 Child vaccination rate reported in 2002 is for June.

6. All the quantitative and structural performance criteria and benchmarks were observed except for the end-September criterion on the publication of the 2001 financial audit of the Central Bank of Mauritania (BCM). The audit report, which was not completed on time by the external auditor, was received by the authorities in mid-October and published on November 12 (Tables 5 and 6). In view of this, the authorities request a waiver for the nonobservance of this performance criterion.

\section{REPORT ON THE DISCUSSIONS}

7. In the context of the last review under the current PRGF Arrangement, discussions focused on policies needed to maintain macroeconomic stability beyond the current program, while reducing poverty and further improving social indicators-as outlined in the 
authorities' poverty reduction strategy. The authorities expressed an interest in a successor PRGF Arrangement with the Fund.

8. The discussions were held essentially on the 2003 budget and the reform of the wage and salary tax, public expenditure management, and the operation of the foreign exchange market. These core issues were emphasized by the Managing Director during his visit to Mauritania on October 14-15 and will be the main focus of the remainder of this report.

\section{A. The 2003 Budget}

9. A slightly revised macroeconomic framework guided the discussions on the 2003 budget. This framework continues to aim at stimulating growth, reducing poverty, and maintaining macroeconomic stability. Public savings are expected to fall with the increase in social and poverty-related spending on the assumption of improved implementation capacity, and consequently government deposits in the banking system will be run down. ${ }^{4}$ Fiscal policy in 2003 should belp support the PRSP's objectives, namely a growth rate of about 5.5 percent with an increase in social and poverty-related spending, while maintaining inflation under 4 percent. The projected overall budget deficit at 2.3 percent of GDP will be more than financed by external resources, leading to further accumulation of government deposits in the banking system (Table 7).

10. Discussions of the $\mathbf{2 0 0 3}$ budget focused on increasing social and poverty-related expenditures, reforming the wage and salary tax, and keeping up the momentum for improved tax collections. The staff stressed the importance of keeping up the good tax collection efforts of the first half of 2002. Capital spending will increase by 1.3 percentage points of GDP (to 11.9 percent), with current expenditures rising concomitantly to allow for needed operations and maintenance. Spending on education and health will increase in line with the medium-term expenditure frameworks and as agreed with the World Bank. In view of the limited implementation capacity, it was not possible to increase social expenditures by more than 0.6 percentage point of GDP despite the availability of resources (Table 3$)^{5}$

\section{A major reform of the wage and salary tax was adopted in the context of the} 2003 budget. Following the reduction in the corporate tax rate in 2002 from 35 percent to 25 percent, the authorities saw a need for reforming the payroll tax and for substantially

\footnotetext{
${ }^{4}$ The minor differences between this framework (Table 7) and that underlying the Poverty Reduction Strategy Paper (PRSP) reflect information that has become available since the preparation of the last staff report. It is expected that this information, and other information that will become available, will be used to revise this framework in the context of the second PRSP progress report.

${ }^{5}$ The reduction ( 0.2 percent of GDP) in poverty-related expenditures in 2003 is due essentially to the additional UM 1 billion (0.4 percent of GDP) allocated to drought-stricken rutal areas in 2002 .
} 
reducing the heavy tax burden on wage earners. ${ }^{6}$ After discussing the revenue and distributional impact of this reform with the mission, the authorities adopted a two-rate structure with a general monthly exemption of UM 10,000, a 15 percent rate on monthly wages below UM 32,500 (about US\$110), and a 40 percent marginal rate on higher wages. The reduction of the burden will benefit the poor the most. Compensatory measures consisting of raising some fees and continued improvement in tax collection, as well as better compliance by the private sector, should limit the net revenue loss of this reform to only 0.3 percent of GDP (Box 1 ).

12. The authorities lowered again the corporate income tax rate in the context of the 2003 budget. Following discussions on the budget and on the reform of the wage and salary tax with the staff, the authorities decided to reduce the corporate income tax rate (BIC) from 25 percent to 20 percent. Given the very small contribution of corporate tax to budgetary revenue ( 2.6 percent in 2001 ), the staff estimates that revenue shortfall, if any, would be negligible (less than 0.02 percent of GDP). In any case, the authorities are committed to introducing contingency measures during 2003 to compensate for any possible shortfall in budgeted tax revenue.

13. The staff expressed concern that this decision may introduce further distortions in the tax system and regretted the fact that it was taken without prior consultation with the Fund. The reform of the wage and salary tax was intended to be aligned with the corporate tax rate. However, with this change and the increased wedge between the corporate tax and the general income tax (IGR) with its top rate at 40 percent, the staff considers that there will be a need to revisit this issue in the context of next year's Article IV consultation discussions with a view to examining the whole income tax structure. FAD technical assistance may be requested to deal with this issue.

\section{B. Public Expenditure Management}

\section{The authorities concurred with the mission's emphasis on the need to further} improve public expenditure management, accountability, and transparency. ${ }^{7}$

- Top prlority is the production of monthly government financial and economic accounts (TOFE). This will require an improvement in the operation of the treasury, which should consistently reconcile its accounts with the movements of the government's accounts held at the BCM and then provide reliable and timely monthly data to the budget department.

\footnotetext{
${ }^{5}$ The current structure of the wage and salary tax is based on 11 average rates ranging from 6 percent to 39 percent, which are high rates by any standard.

${ }^{7}$ The August Review of Standards and Codes (ROSC) mission raised these issues, and the finat report on fiscal ROSC will soon be available.
} 


\section{Box 1. Mauritania: The Reform of the Wage and Salary Tax}

Discussions on the reform of the wage and salary tax (ITS) (Impôt sur les Traitements et Salaires) in the past year centered on the need to reduce the number of brackets in line with those of the general income tax (IGR), while keeping, to the extent possible, the change revenue neutral. With the reduction in the corporate income tax rate from 35 percent to 25 percent in 2002, the need to bring the ITS rates down has become even more pertinent.

The existing ITS is based on eleven brackets with average rates ranging from 6 percent on the lowest salary bracket (UM 4,001-UM 6,000) to 39 percent on the highest salary bracket (greater than UM 100,000, equivalent to US\$350)--very high rates by any standard.

In the context of the discussions on the 2003 budget, the authorities proposed to reduce by half the ITS burden. To this end, they suggested to adopt a unique tax rate or two tates-a proposal made in a 2000 World Bankfinanced study on the reform of direct taxation. Discussions of these proposals focused on reducing the tax burden, limiting the revenue loss to a manageable level, and benefiting the poorer segment of wage earners the most. After running several simulations, it became apparent that a unique rate (unless it is extremely high) would lead to a large loss of revemue and unequal distribution of benefits, favoring high-wage earners.

Hence, the authorities decided to adopt a two-rate structure that would minimize the revenue loss and preserve some progressivity in the tax system. This is based on a general exemption of UM 10,000 , with a 15 percent rate on monthly wages up to UM 32,500 (about US\$110), and a 40 percent marginal rate on wages above this level. This should reduce the average tax contribution of low-wage earners (less than UM 32,500) by 40 percent and that of high-wage earners by about 15 percent. The 40 percent marginal rate seems high, but given that most people ( 99 percent) in the public sector-which was meant to benefit from this reform in the first place-earn less than UM 60,000, the average tax rate for those would not exceed 25 percent (compatible with the corporate tax); for the few that are eaming above UM 100,000 (20 out of 28,554 public sector employees), the average rate would not exceed 30 percent. The staff will explore with the authorities, in the next year or two, the possibility of putting in place a global income tax which aggregates all sources of income including the ITS.

This new structure would entail a revenue loss of UM 2.8 billion (about 1 percent of GDP). To contain this loss, compensatory measures will be adopted in the 2003 budget, including (i) a 50 percent increase in airport and motor vehicles taxes (with an estimated return of UM 220 million); (ii) an increase in the sale price of a square meter of government land from UM 400 to UM 600 (with a return of UM 300 million); and (iii) the new fee on fishing boats (with an estimated revenue of UM 200 million). In addition, revised estimates of all tax categories on the basis of improved and actual collection through August would generate about UM 750 million.

Therefore, the net loss would be linited to UM 1.3 billion or 0.3 percent of GDP. In addition, the authorities firmly believe that better compliance by the private sector would make up for this loss in the next $2-3$ years.

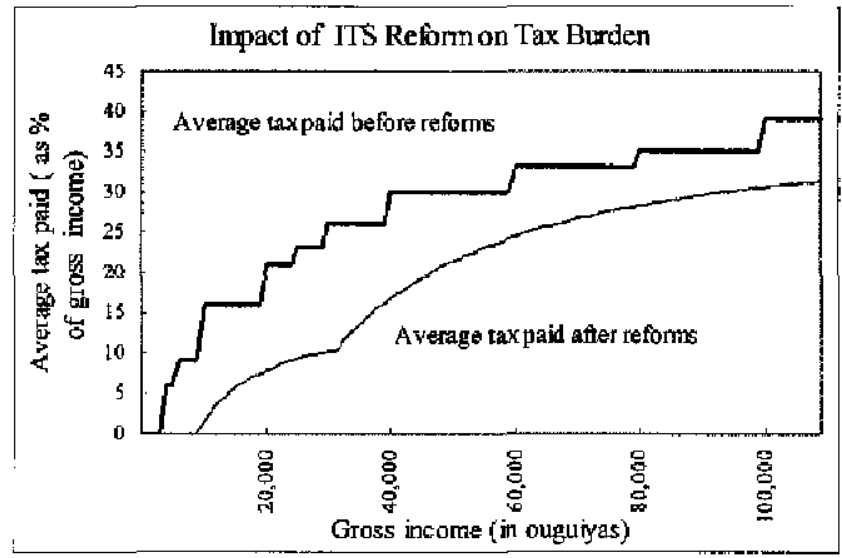


The authorities indicated that these accounts will be prepared regularly beginning in January 2003 and that the budget execution law (loi de règlement) was expected to be submitted to parliament with the 2003 budget, as envisaged. ${ }^{8}$

- Tracking of expenditures. The preparation of the functional budgetary classification and the identification of all budget lines related to poverty reduction were completed. In addition, the quality of the last quarterly report on the execution of projects financed by HIPC resources has improved, especially in terms of broadly assessing their likely social and poverty impact. However, there is still a general need to improve tracking of expenditures in line with the recommendations of the October 2001 and August 2002 FAD missions (Box 2).

- Poverty and social impact analysis (PSIA). The World Bank will provide technical assistance to help the authorities assess the impact of increased spending on education and health. This work should begin in the first half of 2003. In the rural water sector, a study on ways to improve the access, quality, and efficiency of water supply is due to start in early 2003.

- Computerization of expenditures. The mission stressed the importance of expediting the computerization of expenditures following the technical delay in launching the bid. The selection of the consultant is expected before year-end.

- The overall medium-term expenditure framework (MTEF). Following the completion of the MTEF for health, education, infrastructure, and rural and urban development, an overall MTEF was targeted for end-2002. However, the authorities argued that by this time the discussions on the 2003 budget will have been completed, and therefore it will be more useful to prepare an up-to-date MTEF by June 2003 to be used in the preparation of the 2004 budget.

- Implementation capacity. The missions of the World Bank and the Fund stressed the need for a concrete action plan to enhance the country's ability to conceive, implement, and monitor projects. Weak implementation capacity continues to impede poverty reduction and a more significant improvement in social indicators. The mission also requested that a capacity assessment be prepared so that Mauritania can benefit from technical assistance from the West African Technical Assistance Center (AFRITAC).

\section{The Foreign Exchange Market}

\section{The authorities' exchange rate policy continues to aim at maintaining external} competitiveness. The real effective exchange rate depreciated by about 8 percent in the first

\footnotetext{
${ }^{8}$ The treasury accounts were harmonized with the new nomenclature in July 2002 , but the harmonization with local governments is expected before end-November.
} 


\section{Box 2. Mauritania: Implementation Status of Actions to Strengthen Tracking of Poverty-Reducing Public Spending 1/}

$\begin{array}{lcc}\text { Timing } & \text { Status } & \text { Comment } \\ (\mathrm{S} / \mathrm{M}) 2 / & \text { [FI/L/NS) } 3 /\end{array}$

Actjons to strengthen budget formulation

$1 \quad$ Unified 2003 budget, including investment and external financing S

S II

2 Preparation of a budget annex presenting consolidated data from M

NS

Work has been decentralized entities.

3 Quantification and tracking of grants not in budget.

M

4 Preparation of a strategy for improving infonnation and putting in place a system to track spending by grant.

M II

M NS

S NS

2003 budget.

6 Application of budget classiftcation identifying and tracking HIPC including HIPC, using functional classification.

8 Utilization of new functional classification to track all poverty-

Implemented reducing expenditure.

9 Update functional classification to make consistent with $1999 \mathrm{UN}$ S nomenclature

10 Preparation of new classification modules

11 MTEFs included in budget cycle for health and education.

12 MTEFs prepared for nural and urban development, nural infrastruchure: and an overall MTEF.

13 Ensure overall MTEF used to preparc 2004 budget, establishing spending ceilings by ministry.

\section{Actions to strengthen badget execution}

14 Computerization of expenditures in place and implemented.

15 Implementitation of detailed central government chart of accounts for the decentralized entities with the same classification as the government's.

16 The [GF (additional audit borty) reactivated and reinforced by giving it necessary resources.

17 Ensure adoption of the budget execution law for 2001 and the audit of 5 related accounts by the external audit agency (Cour des Comptes).

18 Continue to adopt the budget execution law (for 2002) and audit the 2002 accounts in the statutory time frame.

19 Integrate the Commissariat into the treasury accounting via an interim system.

20 Decentralize HIPC expenditures to line ministries and local govermminnt.

\section{Actions to strengthen budget reporting}

21 Prepare treasury accounting balances, identifying accounts payable on a monthly basis, and prepare a TOFE based on the monthly treasury account balances.

22 Audited accounts are closed within two months of fiscal year-end.

$\begin{array}{ll}\text { II } & \begin{array}{l}\text { Consultant } \\ \text { selection for } \\ \text { project expected } \\ \text { by } 12 / 2002 .\end{array} \\ \text { II } & \text { IGF has five } \\ \text { inspectors. } & \text { Expected to be } \\ \text { II } & \text { approved by } \\ \text { parliament in } \\ \text { early Dex. 2002. }\end{array}$

FI

NS

NS

Expected in $1 / 2003$.

NS

1/ As identified by FAD in the October 2001 assessment teport, and updated in the August 2002 progress report.

$2 / \mathrm{S}=$ Short-term action; $\mathrm{M}=$ Medium-term action.

3/ FI=Fully implemented, II=Implemented partially, NS =Not started. 
seven months of the year. While the inflation rate differentials with trade partners did not appear to widen in favor of Mauritania, this depreciation stemmed essentially from the significant depreciation (about 15 percent) of the ouguiya against the euro. This was also the outcome of continuous focus on the U.S. dollar-which depreciated substantially with respect to the euro-as a benchmark for assessing competitiveness. In view of this sharp depreciation of the ouguiya and the real effective exchange rate (which has been depreciating since June 1998), the staff considers that there is room for some appreciation of the exchange rate without a noticeable impact on external competitiveness. Furthermore, given the slow and steady depreciation of the ouguiya in recent years, reversing this trend could help dampen expectations about further depreciation and discourage speculation. A modest appreciation could be achieved by the need of the BCM to adopt a more aggressive foreign exchange market intervention policy aimed at narrowing the gap between the official rate and the parallel rate (see $\| 17$ ).

16. Reacting to the concern expressed by the mission, the authorities attributed the recent increase in the spread between the official rate and the parallel rate to speculative factors. ${ }^{9}$ Officials at the BCM explained that the spread is due essentially to a clear preference for cash by those who seek anonymity (to avoid taxation) and to speculative behavior on the part of economic agents-a behavior that appears to border on irrationality. In response, in August, the BCM issued two circulars: the first sets limits on transporting and regulates the handling of foreign bank notes beyond a certain level; and the second forces fish exporters to surrender their export proceeds to the BCM, which would then immediately sell 70 percent of these proceeds on the "expanded exchange market" (Marché de change élargi, MCE), while the remaining 30 percent are deposited in foreign currency on the exporters' bank accounts.

17. In the view of the staff, this spread reflects mainly factors related to the behavior of commercial banks and to the BCM's intervention policy (Box 3). First, in view of the traditional and close links between banks and commercial traders, banks limit the supply of foreign exchange to clients from their own groups or their extended families, thus hindering competition in the traded goods sector, which they perceive as more beneficial than engaging in foreign exchange operations. Second, this behavior is influenced by commercial banks' perception that the BCM does not have sufficient reserves to satisfy demand fully, and hence they have to be selective and somewhat discriminatory in their allocation of foreign exchange (this was confirmed by some bankers). Third, the BCM does not intervene as much as needed in the foreign exchange market, either because of poor assessment of market conditions or because of fears of missing the quantitative performance criterion under the Fund-supported program. Fourth, there is a large informal sector that deals essentially with cash and

'Despite the wide range of measures implemented under the current PRGF Arrangement and the comfortable level of international reserves, this spread exceeded 10 percent last August. For more details on the reforms adopted, see Selected Issues (May 10, 2002), Chapter III and Appendix. 
purchases its foreign exchange bank notes mainly from fishermen (artisanal and industrial) and others (Mauritanian workers overseas and immigrants, for example) at a relatively higher rate.

\section{Box 3. Mauritania: The Foreign Exchange Market}

Staff have been concerned by the recent increase in the spread between the official exchange rate and the parallel rate. This spread exceeded 10 percent in August, although it declined to about 6 percent in early November.

It appears that during this period, access to foreign exchange at banks was being selective and sometimes restricted, forcing buyers to resort to exchange bureaus and the informal market, where they pay a bigh premium. At the staff's suggestion, the central bank arranged a meeting with representatives of banks, foreign exchange bureaus, and various groups from the business community on the functioning of the foreign exchange market. Staff attended this meeting as observers.

This meeting was well attended and confirmed the staff's analysis that (i) banks restrict the supply of foreign exchange to their own clients and to their own groups; (ii) banks consider that foreign exchange is in short supply and, therefore, restrictions on the sale of foreign exchange are warranted; and (iii) the public does not understand how the market operates and their right of access to foreign exchange.

In addition to the principal measures that the staff recommend to address this issue ( 19 ), the mission discussed with the authorities the following actions aimed at enhancing the transparency of the foreign exchange market. In particular:

(1) All written requests by customers to banks for the purchase of foreign exchange should be copied to the central bank to enable better monitoring of these requests and to provide a basis to deal with future claims of unfulfilled orders.

(2) The establishment of a central bank foreign exchange policy committee, including the directors of foreign exchange, research, and bank supervision, to coordinate exchange rate policy and make recommendations to the governor of the central bank in this area-taking in particular further account of general economic, banking, and liquidity conditions.

(3) Wide-ranging publicity to clarify the current foreign exchange regime to improve the public's awareness of its rights and obligations regarding access to foreign exchange and to explain the workings of the market. A brochure was prepared in early November. 
18. Against this background, the mission reached an understanding with the authorities on a set of specific measures to address the shortcomings of, and the segmentation in, the foreign exchange market with a view to alleviating any difficulties in acquiring foreign exchange and reducing the spread between the official and parallel market rates. These include:

- Raising the level of BCM intervention in the latter part of this year and in 2003 to increase liquidity in the exchange market and to reassure banks and foreign exchange bureaus that the $\mathrm{BCM}$ can respond to their demand-especially since the international reserves position is very comfortable. Banks should then respond better to the demand by their clients without having to resort to arbitrage between those and their own families and groups. This could be helped by publishing regularly the reserve position of the BCM.

- Meeting regularly with commercial banks to remind them of their responsibility to serve all clients and to enforce the separation between banking and other commercial activities. This would also provide a forum for discussing concerns in the foreign exchange market. In addition, by copying all the requests for foreign exchange to the BCM, the latter will be in a position to monitor any restrictions or irregularities practiced by banks in the sale of foreign exchange.

- $\quad$ Providing signals to the market by announcing daily an opening buy/sell intervention rate, and at the same time eliminating bids at the "best" rate (au mieux), since these bids would withhold useful pricing information that could allow the market to operate better. As the main supplier of foreign exchange, and in view of the still rudimentary nature of the exchange market, the $\mathrm{BCM}$ should play a more active role, including by indicating its willingness to buy foreign exchange in the $\mathrm{MCE}$.

- Undertaking a broad range of actions to enhance the transparency and publicity of the foreign exchange market (Box 3).

19. The mission also stressed that addressing problems in the foreign exchange market by setting restrictions was a step backward. Although the circular on bank notes seemed consistent with regulations in other countries, even in those that have adopted capital account convertibility, the mission argued that quite often in developing countries, these regulations give rise to cumbersome procedures and abuse, thus adversely affecting the business environment. ${ }^{10,11}$ The mission argued strongly against reimposing surrender

\footnotetext{
${ }^{10}$ LEG and MAE revicwed the two circulars and concluded that they do not contravene Mauritania's obligations under Article VIII, Sections 2, 3, and 4.

${ }^{11}$ The mission suggested that custom officials be instructed to be selective in the application of the circular so as not to harass travelers and discussed the possibility of adding one simple question on bank notes to landing cards.
} 
requirements on fishing exports, especially after eliminating all surrender requirements under the PRGF Arrangement, and regretted that this decision had been taken without prior consultation with the staff. The mission maintained that having a clear repatriation policy should obviate the need for surrender requirements, since this would have the same impact on foreign exchange liquidity in the banking system. The authorities responded that in view of the close links between fish exporters and some commercial banks, providing foreign exchange through the MCE should level the playing field for the dernand for foreign exchange by all banks and exchange bureaus. ${ }^{12}$ They also indicated that reversing decisions soon after they were adopted would undermine their credibility and agreed to revisit this issue early next year to reassess the usefulness of this circular. ${ }^{13}$

\section{Monetary Policy and Banking Sector Issues}

\section{Monetary policy seeks to maintain low inflation, while providing room for} sufficient credit to the private sector. Broad money targeting will remain the nominal anchor for maintaining low inflation and will take on an even more important role in managing liquidity and credit with active foreign exchange intervention by the BCM. Accordingly, broad money is targeted to increase by 9.5 percent in 2003 , consistent with a private sector credit growth of 20 percent, based on a projected budget deficit that would entail a significant increase in government deposits in the banking system, and a level of net foreign assets that takes into account the need for the BCM to intervene more aggressively in the foreign exchange market (Tables 2 and 4). While the current level of interest rates seems appropriate (6.5-7.0 percent on treasury bills, and a repo rate of 11 percent), more active foreign exchange market intervention by the BCM could put pressure on liquidity and interest rates. The BCM should stand ready to tighten monetary policy in response to a possible emergence of inflation pressures-due also to a possible lagged impact of exchange rate depreciation-and respond generally to movements in the monetary aggregates through the use of indirect monetary instruments.

\section{The quality of the second quarterly report of the Monetary Policy Committee} has improved. However, the report could improve in several areas to help guide and render the conduct of monetary policy more efficient. In particular, the report should better explain the basis for the decisions made (such as the variations in the stock of treasury bills in the

\footnotetext{
${ }^{12}$ The authorities argued that this policy exists, but that it is very difficult to implement. In addition, they claimed that the elimination of surrender requirements during $2000-01$ had a negative impact on foreign exchange availability.

${ }^{13}$ The mission indicated that abolishing this circular should precede any agreement on a successor PRGF Arrangement.
} 
second quarter) and their impact on monetary aggregates, enhance the coverage of real sector and exchange rate issues, and provide a forward-looking perspective. ${ }^{14}$

\section{Discussions on moving government deposits to the BCM are progressing, and} steady progress is being made in strengthening banking supervision. All the credit concentration ratio targets for end-June set in the contrats programmes were observed (Table 8) ${ }^{15,16}$ The mission discussed an operational approach, on the basis of the note prepared by the BCM, for transferring government deposits to the BCM (Box 4). The BCM will work with the staff in the coming months to agree on a timetable for this transfer and on a market-based credit allocation mechanism that would substitute for the expected shortfall in liquidity at commercial banks. In these discussions, the staff emphasized the need to proceed slowly and cautiously to avoid a banking crisis or a private sector credit crunch.

\section{OTHER KeY IsSUES}

\section{To ensure continued external debt sustainability following the completion point under the enhanced HIPC Initiative, efforts should intensify to secure the delivery of debt relief and improve debt management capacity.}

- Since reaching the completion point in June, the authorities have continued negotiations with all creditors to secure debt relief. On July 8, the Paris Club agreed in principle a stock of debt reduction canceling US\$188 million (in December 1998 NPV terms). ${ }^{17}$ Among multilateral creditors, the Islamic Development Bank Board has approved debt relief for Mauritania, while the Arab Monetary Fund is expected to do so at its annual meeting in December. The authorities have written to all non-Paris Club creditors to secure debt relief on terms comparable to those of the Paris Club, and so far Kuwait (4.2 percent of debt outstanding) and the Saudi Fund (4.4 percent of debt outstanding) have begun negotiations with Mauritania to deliver full debt relief. The authorities should intensify their

\footnotetext{
${ }^{14}$ The MPC was established in January 2002 to strengthen the management and improve the efficiency of monetary policy. The staff has provided detailed comments and suggestions on the first and the second reports with a view to improving the quality.

${ }^{15}$ In the context of the contracts signed with commetcial banks (contrats programmes), most barks shonld observe the target ratios (of 10 percent for individuals and 20 percent for groups) by end-2004. As of now, four out of seven banks have already observed these targets.

${ }^{16}$ Other prudential ratios were observed by all banks, with the exception of the fixed assets capital ratio, which was not observed by one bank in June.

${ }^{17}$ Paris Club creditors also committed on a bilateral basis to grant additional debt relief so that the stock of debt owed to the Paris Club would be reduced from US\$320 to about US\$16 million (in 1998 NPV terms). Bilateral negotiations with Paris Club creditors are now underway and should be completed by end-December.
} 


\section{Box 4. Transferring Government Deposits to the Central Bank}

Government deposits held at commercial banks at end-August 2002 represent approximately 36 percent of the banking sector's deposit base. Of the total held by banks, about 18 percent are project-related deposits. Since January 2002, government deposits have been remunerated at 3 percent, with the rate due to increase with their transfer to the central bank. Banks use these deposits to extend eredit to the private sector and purchase $t$-bills.

Staff has been working closely with the central bank to operationalize the transfer of (nonproject) government deposits from commetcial banks to the central bank. This work is based on a three-year projection of balance sheets and income statements, bank by bank, starting with the most recent data. This initial framework was discussed during the mission with the authorities who will examine this approach and its assumptions carefully in order to set a concrete timetable for this transfer, possibly in the first half of next year. The projections are based on the following assumptions:

- At the level of balance sheets, the main components of bank assets and liabilities such as credit to the private sector and private deposits are assumed to grow in line with the medium-term macroeconomic framework. Since the transfer of government deposits reduces banks" sources of funds, the resulting "liquidity gap" is assumed to be filled by the introduction of a partially collateralized central bank market-based credit allocation mechanism. Other assets and liabilities are projected to grow in line with nominal GDP.

- Projections of banks' income statements hinge on revenue and cost assumptions. Revenue is tied to the growth in assets and the rate of return on credit (excluding bad loans), while operating costs grow in line with nominal GDP. Financial costs include the interest paid on credit auctioned by the central bank and the rate of remumeration of government deposits. The partial collateralization will be made possible through the use of $t$ bills and possibly other commercial bank assets that are classified as low risk.

The transfer schedule essentially boils down to balancing the two competing objectives of accelerating the transfer and keeping the banking system sound, including maintaining profits at acceptable levels. Profits are assumed to be kept by banks as retained earnings, and no dividends are assumed to be distributed in order to improve banks' capitalization.

In the first year, the transfer is facilitated by a one-off decrease in reserve requirements on all deposits (from 4.5 percent to 2 percent). Naturally the ability of banks to carry out a timely transfer while maintaining profits depends on their initial conditions, particularly their profitability and the share of government deposits in their liabilities.

Under the assumptions of the benchmark scenario, the four largest banks would manage to transfer all (nonproject) deposits within three years while maintaining profits at current levels. Half of the transfer would actually take place in the first year, thanks to the lower reserve requirements, with the rest equally split between the second and third years. The remaining four banks would take more than three years to complete the transfer.

Clearly, this approach relies heavily on the introduction of a credit allocation mechanism, details of which were examined in the Selected Issues (May 10,2002) and the assumptions described above. The banking supervision unit at the central bank is closely examining these assumptions, and discussions will need to continue in the coming months to further refine the analysis. 
ongoing efforts with all creditors to secure their participation in the enhanced HIPC Initiative.

- The BCM created a unit to monitor external debt and assess its sustainability, but much more is needed. The authorities agreed to prepare an action plan by early next year to (i) improve coordination between the agencies concerned; (ii) unify the debt databases; and (iii) train staff to improve monitoring and analysis.

\section{The mission stressed the need for prudent management of domestic natural} resources, particularly fish and potentially oil. Given the importance of fishing resources, vigilance is required to minimize the risk of over fishing. ${ }^{18}$ Although the decline in fish catch in 2002 was reported to be on account of climatic factors, the mission urged the authorities to monitor fishing activities closely to ensure that they conform to the agreements signed. While news on oil exploration are encouraging, the commercial viability of oil is not yet confirmed. Nonetheless, and recognizing that benefits from any commercially viable oil exploration were not expected before 2005 , the mission recommended putting in place appropriate systems and procedures early on to ensure efficient and transparent use of potential revenues.

\section{The mission renewed its call for reforming the national social security fund} (CNSS) to redress its precarious financial situation. This should include (i) restructuring of the CNSS to reduce operational costs and increase efficiency (the reports of the experts from the International Labor Organization (ILO) on restructuring should be ready before end2002); (ii) raising and eventually lifting the ceiling on the wage subject to the CNSS contribution; and (iii) to the extent that these measures are not sufficient, increasing the social security contribution rate beyond its current level of 14 pereent. The authorities are still awaiting the final draft of the actuarial study of the ILO before adopting any new measures. Actions on this front are not expected to begin before early next year. ${ }^{19}$

26. While the implementation of the safeguards assessment has begun, there was no further progress reported on the restructuring of the BCM. The continued restructuring of the BCM was planned as part of a financial sector reform project in the context of the World Bank Country Assistance Strategy (CAS) for 2003-05. However, on the basis of a meeting with the World Bank in the field, it appeared that a decision on how to proceed has yet to be taken. The mission communicated the recommendations of the Fund safeguards assessment and their timing to the authorities. Following technical delays by the external auditors, the authorities have published both the BCM's audited financial statements and the related audit opinion on November 12 .

\footnotetext{
${ }^{18}$ These resources represent about 10 percent of GDP, 35 percent of budgetary revenue, and 45 percent of total exports and are a major source of international reserves.

${ }^{19}$ The reform of the CNSS has been discussed extensively in previous reports. If not dealt with immediately, the CNSS would run out of reserves in 3-5 years with an adverse fiscal impact.
} 
27. In view of the continued weakness in the global energy market, the privatization of the electricity company SOMELEC is anlikely to take place soon. The mission relied on the expert opinion of the World Bank staff who, on the basis of discussions with the authorities, concluded that the privatization of SOMELEC could take between 18 and 24 months after relaunching the process, which is not expected before the presidential elections of December $2003 .^{20,21}$

\section{MONITORING AND SUCCESSOR PRGF ARRANGEMENT}

28. The mission reached an understanding with the authorities on a set of indicative quantitative targets in the context of a financial program covering the remainder of 2002 and 2003 (the current arrangement expires on December 20). These quarterly targets should provide continued guidance to the authorities and help them monitor closely the situation in the absence of a Fund-supported program (Tables 6 and 9).

29. In the attached letter of intent, the authorities wish to initiate discussions as soon as possible on a program that could be supported by a successor PRGF Arrangement. This letter discusses briefly some important issues that a new program could address. Over the next few months, the staff will assess the need for such a program by taking stock of past accomplishments as well as failures under the recent PRGF Arrangements and draw lessons for the future.

\section{STAFF APPRAISAL}

30. The Mauritanian authorities have successfully completed their PRGF-supported program. Over the last three years, Mauritania maintained robust economic growth, low inflation, and a comfortable gross foreign reserves position. Having witnessed these achievements and felt their tangible benefits, the authorities' ownership of the program has strengthened-an ownership that is refiected in their strong desire to continue close collaboration with the Fund, preferably in the context of a successor PRGF Arrangement.

\footnotetext{
${ }^{20}$ The privatization of SOMELEC, targeted for end-April 2002, was not completed due to weaknesses in the global energy sector that led to the withdrawal of most of the prequalified companies. Only one company made an offer that was not accepted by the authorities.

${ }^{21}$ According to the World Bank, the privatization of SOMELEC will be carried out in three stages: (i) Reprepare SOMELEC for privatization in the first half of 2003 by hiring soon consultants that will be financed by the World Bank; (ii) prepare a detailed strategy for privatization with the help of advisors (also financed by the Bank) to sound out the market regarding potential investors and to submit various privatization schemes to the government by January 2004; and (iii) select an investment bank to begin the transaction in the first quarter of 2004 .
} 
31. The reaching of the completion point under the enhanced HIPC Initiative represents both a major achievement and an important challenge. Debt relief under the HIPC initiative reduced the external debt burden to a sustainable level and would allow for increasing social and poverty-related spending. However, the authorities should improve their debt management capacity to ensure that external debt indicators remain sustainable and improve the transparency of public spending so that debt relief is efficiently used to raise living standards.

32. Despite its strong performance under the PRGF Arrangement, Mauritania has a long way to go in its fight against poverty. While achieving macroeconomic stability and external debt sustainability have set the stage for strong economic growth and poverty reduction, social indicators remain weak, and about half of the population still lives in poverty. The implementation of the poverty reduction strategy so far has been successful, but considerable and persistent efforts are needed to ensure a sustained and equitable reduction in poverty. This is indeed the key challenge for the future.

33. This, however, will not be an easy task. Faced with relatively limited resources and a small population dispersed thinly across a large and mainly desert landscape, providing social services and income-generating opportunities to the whole population, particularly in rural areas, is very costly and will require substantial efforts to put in place a concrete action plan to strengthen project implementation and monitoring capacity. At the same time, the hard-won macroeconomic stability and external debt sustainability will need to be maintained.

\section{Oil discovery, if commercially viable, could provide a much-needed support in} the fight against poverty. While oil revenues would not be forthcoming any time soon, even if the commercial drilling begins next year, nonetheless the authorities should put in place appropriate systems and procedures early on to ensure an efficient and transparent use of these potential resources and thus avoid the "oil curse" that has afflicted some oil producing countries.

35. Improving the functioning of the foreign exchange market is crucial for private sector investment and growth. The efficiency and transparency of the foreign exchange market is a must for securing investor confidence. The increased spread between the official rate and the parallel rate and the reported difficulties in obtaining foreign exchange from commercial banks represent a major business impediment and could erode the significant gains in competitiveness. Commercial banks should operate as real financial intermediaries that serve all clients rather than restrict their activities to their own groups. The BCM will need to take an active market-based role in the foreign exchange to satisfy the demand and dampen negative market expectations and speculation, especially when reserves are high and competitiveness is not an issue.

36. Fiscal policy in $\mathbf{2 0 0 3}$ aims at increasing social spending and reforming the payroll tax while preserving tax revenues. The authorities should move forcefully to 
accelerate social spending and improve the execution rate of related projects, while ensuring efficiency. The reform of the payroll tax is a much-needed measure to reduce the heavy burden on wage earners and reduce tax evasion by the private sector. However, the reduction in the corporate tax rate to 20 percent raises questions about possible distortions in the general income tax structure, which should be re-examined next year in the context of the 2003 Article IV consultations. The authorities should ensure that revenue loss from tax reform be contained through adopting the identified compensatory measures and implementing contingency measures to compensate for any shortfall from the 2003 revenue target. The mission stresses the importance of keeping the tax base sound, given the temporary nature of grants and HIPC assistance and the vulnerability of some budgetary revenues.

37. Strong efforts are needed to improve further transparency and accountability of the fiscal accounts. The staff welcomes progress made in tracking poverty-related expenditures financed by HIPC resources through the quarterly reports and in accounting for total budgetary expenditures through the preparation of the budget execution law (loi de règlement) for 2001. However, top priority should be placed on addressing the weaknesses of the accounting system and the quality of the monthly fiscal reports.

38. In view of the continued strong performance in 2002, the staff recommends completion of the sixth and last review under the PRGF Arrangement and supports the authorities' request for a waiver. 
Table I. Mauritania: Selected Economic and Financial Indicators, 1999-2003

\begin{tabular}{|c|c|c|c|c|c|c|}
\hline & 1999 & 2000 & 2001 & $\frac{\text { Prog. }}{2002}$ & $\begin{array}{l}\text { Rev. } \\
\text { Proj. }\end{array}$ & Proj. \\
\hline & \multicolumn{6}{|c|}{ (Period percentage changes; unless otherwise noted) } \\
\hline \multicolumn{7}{|l|}{ National income and prices } \\
\hline GDP at constant prices & 5.2 & 5.2 & 4.6 & 5.1 & 4.2 & 5.3 \\
\hline GDP deflator & 3.8 & 5.7 & 5.0 & 3.6 & 3.6 & 4.0 \\
\hline Consumer price index (period average) & 4.1 & 3.3 & 4.7 & 4.0 & 4.0 & 4.0 \\
\hline Consumer price index ( 12 months, end of period) & 1.9 & 5.6 & 1.7 & 5.6 & 6.5 & 3.0 \\
\hline \multicolumn{7}{|l|}{ External sector } \\
\hline Exports, f.o.b. (in U.S. dollars) & -7.4 & 3.5 & 0.1 & -4.6 & -6.9 & 2.4 \\
\hline Emports, f.o.b. (in U.S. dollars) & -14.9 & 8.1 & 8.2 & 7.2 & 9.0 & 9.3 \\
\hline Export volume & 5.6 & -0.4 & -6.3 & 4.4 & -2.8 & 1.6 \\
\hline Lmport volume & -12.6 & 6.7 & 10.7 & 9.0 & 10.8 & 7.6 \\
\hline Terms of trade & -10.0 & 2.5 & 9.2 & -7.2 & -2.7 & -0.8 \\
\hline Norninal effective exchange rate $1 /$ & 1.0 & -4.6 & -1.1 & $\ldots$ & -7.6 & $\ldots$ \\
\hline Real effective exchange rate $1 /$ & 1.1 & -3.8 & 1.0 & $\ldots$ & -8.1 & $\ldots$ \\
\hline \multicolumn{7}{|l|}{ Money and credit } \\
\hline Money and quasi-money $2 /$ & 5.1 & 12.8 & 17.3 & 9.1 & 11.0 & 9.5 \\
\hline Net foreign asșets $2 /$ & 24.1 & 58.1 & 2.2 & 66.6 & 77.8 & 4.1 \\
\hline Net domestic assets $2 /$ & -19.0 & -45.3 & 15.1 & -57.5 & -66.8 & 5.3 \\
\hline Domestic credit $2 /$ & -10.1 & -26.0 & 21.9 & -54.2 & -60.2 & 5.3 \\
\hline Credit to the government $2 /$ & -39.5 & -62.5 & -8.8 & -93.1 & -94.6 & -34.0 \\
\hline Credit to the economy 2 & 29.4 & 36.5 & 30.8 & 38.9 & 34.4 & 39.3 \\
\hline Velocity of money & 6.9 & 6.8 & 6.3 & 6.3 & 6.3 & 6.3 \\
\hline \multirow[t]{2}{*}{ Interest rale $3 /$} & $10-11$ & $8-9$ & 8.0 & 8.0 & 8.0 & 8.0 \\
\hline & \multicolumn{6}{|c|}{ (In percent of GDP; unless otherwise noted) } \\
\hline \multicolumn{7}{|l|}{ Investment and savings } \\
\hline Investment 4/ & 17.1 & 28.6 & 26.0 & 24.7 & 24.6 & 26.0 \\
\hline National saving & 21.2 & 29.4 & 23.9 & 28.5 & 33.9 & 22.3 \\
\hline \multicolumn{7}{|l|}{ Consolidated government operations } \\
\hline Revenue, excluding grants & 27.1 & 25.3 & 20.6 & 37.1 & 37.2 & 29.3 \\
\hline Expenditure and net lending & 25.0 & 29.6 & 26.0 & 30.8 & 30.9 & 31.6 \\
\hline Overall surplus or deficit ( - ) excluding grants 5/ & 2.1 & -4.4 & -5.5 & 6.3 & 6.3 & -2.3 \\
\hline Prinary balance excluding grants (deficit -) $5 f$ & 5.6 & -1.2 & -2.6 & 9.1 & 9.3 & 0.4 \\
\hline \multicolumn{7}{|l|}{ External sector } \\
\hline \multicolumn{7}{|l|}{ Current account balance } \\
\hline Excluding official transfers & -4.2 & -5.8 & -9.8 & 0.0 & 1.2 & -12.5 \\
\hline Including official transfers & 4.1 & 0.8 & -2.2 & 3.8 & 9.3 & -3.7 \\
\hline Debt outstanding & 201,4 & 207.8 & 214.1 & $\ldots$ & $\ldots$ & $\ldots$ \\
\hline Debl servjee ratio before rescheduling & & & & & & \\
\hline (in percent of exports of GNFS) $6 /$ & 36.4 & 36.3 & 31.4 & 27.0 & 27.0 & 24.6 \\
\hline Debt service ratio after rescheduling & & & & & & \\
\hline (in percent of exports of GNFS) $6 /$ & 22.4 & 24.0 & 15.5 & 12.3 & 12.3 & 11.4 \\
\hline Gross official reserves (in months of imports of GNFS) & 5.8 & 7.0 & 6.9 & 8.0 & 8.2 & 6.9 \\
\hline \multicolumn{7}{|l|}{ Memorandum items: } \\
\hline Ouguiya/US\$ exchange rate (period average) & 209.5 & 240.0 & 254.3 & $\ldots$ & $\ldots$ & .. \\
\hline \multicolumn{7}{|l|}{ Current account balance, } \\
\hline excluding official transfers (in millions of U.S. dollars) & $-41,4$ & -55.8 & -96.9 & 0.2 & 11.4 & -131.0 \\
\hline Nominal GDP (in billions of ouguiyas) & 206.5 & 229.4 & 252.0 & 267.3 & 271.9 & 297.6 \\
\hline GDP per capila (in U.S. dol]ars) & 383.1 & 361.2 & 363.8 & 349.7 & 354.4 & 362.1 \\
\hline
\end{tabular}

Sources: Data provided by the Mauritanian authorities; and Fund staff estimates and projections.

1/ Numbers for 2002 are based on January-July actual average.

2/ In percent of broad money at the beginning of the period, adjusted starting from 2000 to include two additional banks.

3/ Interest rates on 12 months passbook savings.

4/ The sharp increase in 2000 reflocts mainly new investments in the telecom sector, an increase in poverty reduction investment financed by debt relief under the HIPC, and a rebound in SNTM investment.

5/ The increase in the deficit in 2000 is due mainly to the cash advance granted by the governtment to the telecom company Mauritel.

6/ Until 1999, these ratios include Paris Club rescheduled debt on Naples terms. For the years 2000, 2001, and 2002, they include rescheduling under Cologne terms by Paris Club creditors, comparable treatment by non-Paris Club bilaterals, and HIPC intcrim assistance, as reported in Masritania's decision point document. 
Table 2. Mauritania: Balance of Payments, 1999-2003

(In millions of U.S. dollars; unless otherwise noted)

\begin{tabular}{|c|c|c|c|c|c|c|c|}
\hline & \multirow{2}{*}{$\frac{\text { Actual }}{1999}$} & \multirow{2}{*}{$\frac{\text { Actual }}{2000}$} & \multirow{2}{*}{$\frac{\text { Actual } 1 /}{2001}$} & \multirow{2}{*}{$\frac{\text { Progratry }}{2002}$} & \multirow{2}{*}{$\begin{array}{r}\begin{array}{c}\text { Adjusted } \\
\text { Progran } 2 /\end{array} \\
2002\end{array}$} & \multicolumn{2}{|c|}{ Projeclions } \\
\hline & & & & & & 2002 & 2003 \\
\hline Tracie balance & 28.4 & 15.2 & -11.5 & -53.1 & -53.1 & -67.5 & -95.9 \\
\hline Exports & 333.1 & 344.7 & 345.1 & 329.3 & 329.3 & 321.4 & 329.2 \\
\hline Of which: irou dre & 177.1 & 194.1 & 188.3 & 173.9 & 173.9 & 178.0 & 181.3 \\
\hline Iruports, t.e.b. & -304.7 & -329.5 & -356.7 & +382.4 & -382.4 & -388.8 & -425.1 \\
\hline Of which: petroleum produets & -61.0 & -99.4 & -94.5 & -105.1 & -105.1 & -108.3 & -113.5 \\
\hline Services (net) $3 /$ & -112.2 & -106.4 & $-13,3$ & 3.1 & 3.1 & 29.6 & .73 .8 \\
\hline Nonfactor services & -136.0 & -125.4 & -110.5 & -129.5 & -129.5 & -117.7 & -144.8 \\
\hline $\begin{array}{l}\text { Factor services 3/ } \\
\text { Of which: }\end{array}$ & \multicolumn{6}{|c|}{ Of which: } & 71.0 \\
\hline Fish license payment & 57.2 & 47.5 & 0.0 & 154.8 & 154.8 & 161.6 & 84.2 \\
\hline Interest payjnents due & -36.6 & -38.3 & -33.2 & .33 .2 & -33.2 & -33.1 & $-\mathbf{3 1 . 7}$ \\
\hline Privale unrequited transfers (net) & 42.4 & 35.4 & 47.9 & 50.1 & 50.1 & 49.3 & 38.6 \\
\hline Current account (excluding official transfers) & -41.4 & -55.8 & $-96,9$ & 0.2 & 0.2 & 11.4 & -131.0 \\
\hline Official transfers $2 / 3 /$ & 81.4 & 63.4 & 75,6 & 36,9 & 72.2 & 81.0 & 92.6 \\
\hline Of which: multilateral HIPC assistance $2 f$ & & & 33.4 & 0.0 & 35.3 & 37.3 & 46.9 \\
\hline Current account (including official transfers) & 40.0 & 7.6 & -21.3 & 37.1 & 72.4 & 92.5 & -38.5 \\
\hline Capital account & -58.9 & 5.2 & -42.8 & -38.0 & -38.0 & -40.0 & -20.1 \\
\hline Direct investment $4 /$ & 0.0 & 40.1 & 14.4 & 17.7 & 17.7 & 15.5 & 16.7 \\
\hline Official medium- and long-tenm loans & -38.2 & -8.0 & -29.8 & -31.7 & -31.7 & +34.2 & .36 .8 \\
\hline Disbursements & 48.0 & 75.7 & 45.0 & 42.6 & 42.6 & 42.7 & 37.6 \\
\hline Principal due & -86.3 & -83.7 & -74.9 & -74.3 & -74.3 & -77.0 & $-74,4$ \\
\hline Other capital and errors and omissions & -20.6 & -26.9 & $-27,3$ & -24.0 & -24.0 & -21.3 & 0.0 \\
\hline Overall balanec & -18.8 & 12.8 & -64.1 & -0.9 & 34.4 & 52.5 & .58 .5 \\
\hline Financing & 18.9 & -12.8 & 64.0 & 0.9 & -34.4 & -52.5 & 46.4 \\
\hline Net foreign assets (excluding amears\}) & .23 .4 & -59.4 & 4.5 & -92.1 & -92.1 & -107.7 & 4.2 \\
\hline Central bank & -24.1 & -58.8 & 2,4 & -90.1 & -90.1 & -106.3 & 6.4 \\
\hline Assets & -21.0 & -55.4 & -3.3 & -85.6 & -85.6 & -101.7 & 29.2 \\
\hline Liabilities & -3.1 & +3.4 & 5.6 & -4.5 & -4.5 & -4.5 & -22.8 \\
\hline Of which: use of Fund resources (net) & 1.3 & -3.0 & 10.0 & -0.4 & -0.4 & -0.4 & -18.0 \\
\hline Conmencial banks (net) & 0.7 & -0.6 & 2.1 & -2.0 & -2.0 & -1.5 & -2.2 \\
\hline Exceptional financing & 42.2 & 46.7 & 59.5 & 93.0 & 57.7 & $\$ 5.2$ & 42.2 \\
\hline Accruals $(+) /$ reductions ( - ) of arrears 5 / & 30.6 & -180.0 & 13.3 & 7.5 & 7.5 & 8.4 & 6.3 \\
\hline Deht reschednling and cancellation $6 /$ & 11.6 & 226.7 & 28.0 & 27.5 & 27.5 & 13.0 & 15.1 \\
\hline Multilateral HIPC assistance $7 /$ & $\ldots$ & $\ldots$ & 0.0 & 35.3 & 0.0 & 10.4 & 0.0 \\
\hline Qther identified resources \& & $\ldots$ & s.t. & 18.2 & 22.7 & 22.7 & 23.5 & 20.9 \\
\hline Financing gap $\{$ excess $(+y /$ shortfall $(-))$ 9/ & 0.0 & 0.0 & 0.0 & 0.0 & 0.0 & 0.0 & -12.1 \\
\hline \multicolumn{8}{|l|}{ Memorandum items: } \\
\hline \multicolumn{8}{|l|}{ Current acceunt deficit } \\
\hline Inchuding official transfers (percent of GDP) & 4.1 & 0.8 & -2.2 & 3.8 & 7.4 & 9.3 & -3.7 \\
\hline Excluding official transfers (percent of GDP) & -4.2 & -5.8 & -9.8 & 0.4 & 0.0 & 1.2 & -12.5 \\
\hline Overall balance (percent of GDP) & -1.9 & 1.3 & -6.5 & 3.5 & 3.5 & 5.3 & -5.6 \\
\hline \multicolumn{8}{|l|}{ Gross official reserves (end of period) } \\
\hline In millians of U.S. dollars & 228 & 283 & 286 & 372 & 372 & 388 & 359 \\
\hline In monthe of inports of goods and NFS & 5.8 & 7.0 & 6.9 & 8.0 & 8.0 & 8.2 & 6,9 \\
\hline In menths of subsequent year imports & 5.4 & 6.5 & 6.5 & 7.5 & 7.5 & 7,4 & 6.6 \\
\hline In percent of short-term debt (after relief) & 271 & 374 & 640 & 645 & 645 & 642 & 612 \\
\hline In percent of bread money & 175 & 217 & 199 & 247 & 247 & 259 & $\ldots$ \\
\hline \multicolumn{8}{|l|}{ Debt service ratios $10 f$} \\
\hline Before debt relief & 36.4 & 36.3 & 31.4 & 27,0 & 27.0 & 27.0 & 24,6 \\
\hline After debt relief (cxcluding arrears' reduction) & 22.4 & 24.0 & 15.5 & 12.3 & 12.3 & 12.3 & 11.4 \\
\hline
\end{tabular}

Sources: Data provided by the Mauritanian anthorities; and Fund staff estimates and projections.

1/ Reflecting the late arrival of EU fishing royalties.

2f Includes HIPC interim assistance up to mid-2002 and assistance agreed upon beyond the completion poitt from the MiF, World Bank, and A.tDB.

3/ Includes the fix ad part of fishing royalties under the EU tishing agreenent. In earlier presentations, these were included in official transfers,

$4 / 2000$ and 2001 reflect privatization of telecommonications.

5/ The reduction of arrears in 2000 results from Arab credifors agreeing on rescheduling terms comparable to those agreed with the Paris Qlub. The accumulation of amears from 2001 reflects debt service due to bilateral cueditors who have not yet agreed to rescheduling.

6/ Already agreed. It reflects Paris Club flow restheduling on Cologne lueng from July 1099-June 2002, rescheduling on comparable terms from the Arab funds FKDEA and FSD and the Saudi govertmenc. Also reflects stock reschedaling agreed by the Paris Chub in July 2002 , but perding bilateral agreements.

$7 /$ HIPC assistance expected after completion point but not yet agreed upon by multilateral creditors. Full agreaments expected by 2003.

8/ In 2002, reflects AfDB and EU. For 2003 , reflects. Warld Bank and EU.

9/ Sources of financing not yet identified.

10/ Bxcludes debt service an passive debt (debt not claimed by creditors) in percent of exports of goods and services. 
Table 3. Mauritania: Consolidated Government Financial Operations, 2000-03

\begin{tabular}{|c|c|c|c|c|c|c|c|c|}
\hline & \multirow{2}{*}{$\frac{2000}{\text { Actual }}$} & \multirow{2}{*}{$\frac{2001}{\text { Actual }}$} & \multicolumn{2}{|c|}{ June 2002} & \multicolumn{3}{|c|}{2002} & \multirow{2}{*}{$\frac{2003}{\text { Proj. }}$} \\
\hline & & & Prog. & $\overline{\text { Actual }}$ & Budget & Prog. & Rev. Prog. & \\
\hline & \multicolumn{8}{|c|}{ (In billions of ouguiyas) } \\
\hline Total revenue & 58.0 & 51.8 & 48.1 & 49.7 & 78.1 & 99.2 & 101.3 & 87.1 \\
\hline Tax revenue & 33.3 & 36.4 & 18.2 & 18.9 & 38.9 & 38.5 & 39.6 & 42.6 \\
\hline Tax on income and profits & 10.6 & 11.3 & 5.5 & 5.9 & 11.7 & 11.8 & 12.2 & 11.5 \\
\hline Other direct taxes & 0.5 & 0.6 & 0.2 & 0.3 & 0.5 & 0.5 & 0.6 & 0.8 \\
\hline Taxes on goods and services & 16.5 & 18.2 & 9.9 & 9.7 & 20.3 & 20.0 & 20.3 & 22.9 \\
\hline Taxes on international trade & 5.5 & 6.1 & 2.5 & 2.8 & 6.1 & 6.0 & 6.4 & 7.1 \\
\hline Nontax revenue & 24.6 & 15.4 & 29.9 & 30.8 & 39.2 & 60.6 & 61.6 & 44.6 \\
\hline Fishing royalties and penalties & 16.4 & 5.3 & 23.8 & 24.8 & 27.4 & 48.8 & 51.2 & 32.1 \\
\hline Of which: EU fish royalties & 12.2 & 1.1 & 21.0 & 22.4 & 22.9 & 44.1 & 47.1 & 27.8 \\
\hline Revenue from public enterprises $1 /$ & 4.1 & 3.6 & 2.6 & 2.4 & 5.6 & 5.7 & 4.1 & 4.6 \\
\hline Other $2 /$ & 4.0 & 6.5 & 3.5 & 3.6 & 6.2 & 6.2 & 6.3 & 7.9 \\
\hline Expenditure and net lending & 68.1 & 65.6 & 38.0 & 38.1 & 82.6 & 82.4 & 84.1 & 94.0 \\
\hline Current expenditure & 39.2 & 42.2 & 24.3 & 24.4 & 51.6 & 51.4 & 52.1 & 57.5 \\
\hline Wages and salaries & 11.0 & 12.2 & 6.6 & 6.5 & 13.0 & 13.0 & 13.0 & 14,0 \\
\hline Goods and services & 13.0 & 14.3 & 10.1 & 10.0 & 21.6 & 21.6 & 21.6 & 25.5 \\
\hline Current transfers & 3.6 & 4.0 & 2.2 & 2.1 & 4.4 & 4.4 & 4.4 & 4.9 \\
\hline Military expenditure & 4.2 & 4.4 & 2.4 & 2.4 & 4.9 & 4.9 & 4.9 & 5.1 \\
\hline Interest on public debt & 7.4 & 7.2 & 3.0 & 3.4 & 7.7 & 7.5 & 8.2 & 8.0 \\
\hline Capital expenditure and net lending & 28.7 & 23.1 & 13.7 & 13.7 & 30.7 & 30.7 & 31.7 & 36.2 \\
\hline Fixed capital formation $3 /$ & 16.9 & 20.5 & 12.8 & 12.4 & 28.7 & 28.7 & 28.7 & 35.5 \\
\hline \multicolumn{9}{|l|}{ Of which: } \\
\hline Financed by HШPC interim assistance & 2.6 & 4.2 & 6.0 & 7.0 & 8.0 & 8.0 & 8.0 & ... \\
\hline Restructuring and net lending 4/ & 11.8 & 2.6 & 0.9 & 1.2 & 2.0 & 2.0 & 3.0 & 0.7 \\
\hline Other expenditure & 0.2 & 0.4 & 0.0 & 0.0 & 0.3 & 0.3 & 0.3 & 0.2 \\
\hline Balance (deficit -) & -10.1 & -13.8 & 10.1 & 11.6 & -4.5 & 16.7 & 17.1 & -6.8 \\
\hline Financing & 10.1 & 13.8 & -10.1 & -11.6 & 4.5 & -16.7 & -17.1 & 6.8 \\
\hline External (net) & 2.5 & 1.0 & 3.5 & 1.4 & 4.4 & 3.9 & 3.5 & 4.0 \\
\hline Grants & 2.7 & 4.0 & 3.3 & 2.5 & 7.1 & 7.1 & 7.3 & 6.6 \\
\hline Net borrowing & -0.2 & -3.1 & 0.2 & -1.2 & -2.7 & -3.2 & -3.7 & -2.6 \\
\hline Domestic (net) & -19.4 & -3.4 & -20.3 & -20.9 & -34.5 & -35.5 & -36.2 & -14.1 \\
\hline Banking system & -18.2 & -2.9 & -20.6 & -20.9 & -14.0 & -36.0 & -36.7 & -14.6 \\
\hline Nonbank & -1.2 & -0.5 & 0.3 & 0.0 & -0.5 & 0.5 & 0.5 & 0.5 \\
\hline Exceptional external financing & 10.8 & 12.6 & 6.8 & 7.9 & 14.5 & 14.8 & 15.5 & 16.9 \\
\hline \multicolumn{9}{|l|}{ Memoranđum items: } \\
\hline Total HIPC assistance & 11.9 & 17.0 & $\ldots$ & $\ldots$ & 19.2 & 19.5 & 15.5 & 22.9 \\
\hline
\end{tabular}


Table 3. Mauritania: Consolidated Government Financial Operations, 2000-03

\begin{tabular}{|c|c|c|c|c|c|c|c|c|}
\hline & \multirow{2}{*}{$\frac{2000}{\text { Actual }}$} & \multirow{2}{*}{$\frac{2001}{\text { Actual }}$} & \multicolumn{2}{|c|}{ June 2002} & \multicolumn{3}{|c|}{2002} & \multirow{2}{*}{$\frac{2003}{\text { Proj }}$} \\
\hline & & & Prog. & Actual & Budget & Prog. 1 & Rev. Prog. & \\
\hline & \multicolumn{8}{|c|}{ (In percent of GDP) } \\
\hline Revenue and grants & 26.4 & 22.2 & 19.2 & 19.2 & 31.2 & 39.8 & 39.9 & 31.5 \\
\hline Total revenue excluding grants & 25.3 & 20.6 & 18.0 & 18.3 & 28.5 & 37.1 & 37.2 & 29.3 \\
\hline Tax revenue & 14.5 & 14.4 & 6.8 & 6.9 & 14.2 & 14.4 & 14.6 & 14.3 \\
\hline Nontax revenue & 10.7 & 6.1 & 11.2 & 11.3 & 14.3 & 22.7 & 22.7 & 15.0 \\
\hline Grants & 1.2 & 1.6 & 1.2 & 0.9 & 2.6 & 2.7 & 2.7 & 2.2 \\
\hline Expenditure and net lending & 29.7 & 26.0 & 14.2 & 14.0 & 30.2 & 30.8 & 30.9 & 31.6 \\
\hline Current & 17.1 & 16.7 & 9.1 & 9.0 & 18.9 & 19.2 & 19.2 & 19.3 \\
\hline Capital formation & 7.4 & 8.1 & 4.8 & 4.6 & 10.5 & 10.7 & 10.6 & 11.9 \\
\hline Other (including net lending) & 5.2 & 1.2 & 0.4 & 0.5 & 0.8 & 0.9 & 1.2 & 0.3 \\
\hline Balance excluding grants (deficit $=-$ ) & -4.4 & -5.5 & 3.8 & 4.3 & -1.6 & 6.3 & 6.3 & -2.3 \\
\hline Balance excluding grants and 2001 fishing roy & -4.4 & -5.5 & -3.9 & -3.2 & -1.6 & -1.4 & -1.2 & -2.3 \\
\hline Balance including grants (deficit $=-$ ) & -3.2 & -3.9 & 5.0 & 5.2 & 1.0 & 8.9 & 9.0 & -0.1 \\
\hline Primary balance & -1.2 & -2.6 & 4.9 & 5.5 & 1.2 & 9.1 & 9.3 & 0.4 \\
\hline Additional revenue from HJPC relief & 0.9 & 1.8 & $\ldots$ & $\ldots$ & 1.7 & 1.8 & 0.0 & 2.0 \\
\hline Social expenditure & 7.3 & 8.0 & $\ldots$ & 4.2 & 11.1 & 11.4 & 11.5 & 12.1 \\
\hline Education expenditure & 4.4 & 4.4 & $\ldots$ & 2.2 & 5.7 & 5.8 & 5.7 & 5.9 \\
\hline Health expenditure & 1.6 & 1.9 & $\ldots$ & 1.2 & 3.3 & 3.4 & 3.3 & 3.8 \\
\hline Poverty rechuction expenditure & 1.3 & 1.6 & $\ldots$ & 0.8 & 2.2 & 2.2 & 2.5 & 2.3 \\
\hline
\end{tabular}

Sources: Data provided by the Mauritanian authorities; and Fund staff estimates and projections.

1/ Includes SDR 3.76 million (for 2000), SDR 6.16 million (for 2001), and SDR 6.96 million (for 2002) of HIPC relief from the Fund transferred to the budget by the BCM.

2/ For 2000-02, includes the transfer to the budget of debt service relief granted on public enterprise debt, as requested under the HIPC Initiative.

$3 /$ Includes additional expenditures financed by the interim relief from the HIPC Initiative (UM 2.6 billion in 2000, UM 4.2 billion in 2001, and UM 8 billion in 2002).

4/ Includes a shareholder's advance to Mauritel for UM 9.4 billion and a participation in the capital increase of Chinguetti Bank for UM 750 million in 2000. 
Table 4. Mauritania: Summary Monetary Accounts, 2001-03

\begin{tabular}{|c|c|c|c|c|c|c|c|c|}
\hline & \multirow[b]{4}{*}{2001} & \multicolumn{6}{|c|}{$20021 / 2 /$} & \multirow{4}{*}{$\frac{200331}{\text { PIog. }}$} \\
\hline & & \multirow{3}{*}{$\begin{array}{l}\text { Original } \\
\text { Program }\end{array}$} & \multicolumn{2}{|c|}{ June } & \multirow{3}{*}{$\begin{array}{r}\text { Adjusted } \\
\text { Actual }\end{array}$} & \multicolumn{2}{|c|}{ December } & \\
\hline & & & & Adjusted & & \multirow{2}{*}{$\begin{array}{l}\text { Original } \\
\text { Program }\end{array}$} & \multirow[b]{2}{*}{ Projected } & \\
\hline & & & Actual & Program & & & & \\
\hline & \multicolumn{8}{|c|}{ (In millions of ouguiyas; end of period) } \\
\hline \multicolumn{9}{|l|}{ I. Monetary authorities } \\
\hline Net foreign assets & 23,044 & 37,516 & 42,388 & 37,516 & 42,388 & 50,775 & 52,473 & 53,550 \\
\hline Assets & 72,248 & 88,719 & 92,906 & 88,719 & 92,906 & 101,371 & 103,040 & 100,491 \\
\hline Liabilities & $-49,204$ & $-51,203$ & $-50,518$ & $-51,203$ & $-50,518$ & $-50,596$ & $-50,567$ & $-46,941$ \\
\hline \multicolumn{9}{|l|}{ Of which: } \\
\hline Use of Fund credit & 27,771 & $\ldots$ & 27,965 & $\ldots$ & 27,965 & $\ldots$ & ... & ... \\
\hline Net domestic assets & $-13,321$ & $-27,250$ & $-32,050$ & $-27,250$ & $-32,050$ & $-40,165$ & $-41,681$ & $-41,738$ \\
\hline Net credit to the government & -51.501 & $-64,224$ & $-68,696$ & $-64,224$ & $-68,696$ & $-77,139$ & $-78,328$ & $-75,518$ \\
\hline Clains & 16,912 & 16,912 & 16,912 & 16,912 & 16,912 & 16,912 & 16,912 & 16,912 \\
\hline Deposits & $-68,413$ & $-81,136$ & $-85,608$ & $-81,136$ & $-85,608$ & $-94,051$ & $-95,240$ & $-92,430$ \\
\hline Credit to banks & 1,539 & 978 & 969 & 978 & 969 & 1,539 & 1,539 & 1,539 \\
\hline Other items net & 35,663 & 34,457 & 34,138 & 34,457 & 34,138 & 34,457 & 34,138 & 31,272 \\
\hline Reserve money & 9,723 & 10,266 & 10,338 & 10,266 & 10,338 & 10,610 & 10,792 & 11,812 \\
\hline Currency in circulation & 6,688 & 7,062 & 6,740 & 6,696 & 6,375 & 7,298 & 7,423 & 8,125 \\
\hline Bank Jeserves & 3,035 & 3,205 & 3,598 & 3,570 & 3,963 & 3,312 & 3,369 & 3,687 \\
\hline \multicolumn{9}{|l|}{ II. Monetary survey } \\
\hline Net foreign assets & 24,781 & 39,609 & 44,351 & 39,774 & 44,515 & 53,134 & 54,866 & $5,6,634$ \\
\hline Central bank & 23,044 & 37,516 & 42,388 & 37,516 & 42,388 & 50,775 & 52,473 & 53,550 \\
\hline Comtnercial banks & 1,737 & 2,094 & 1,963 & 2,258 & 2,128 & 2,359 & 2,393 & 3,084 \\
\hline Net domestic assets & 13,869 & 1,200 & $-3,721$ & 1,708 & $-3,212$ & $-10,958$ & $-11,968$ & $-9,680$ \\
\hline Domestic credit & 1,203 & $-10,169$ & $-14,074$ & $-9,410$ & $-13,315$ & $-22,327$ & $-22,071$ & $-19,782$ \\
\hline Net credit to the government & $-68,714$ & $-89,306$ & $-89,709$ & $-89,206$ & $-89,609$ & $-105,251$ & $-105,283$ & $-119,854$ \\
\hline Claims & 13,829 & 12,414 & 13,549 & 12,514 & 13,649 & 10,781 & 11,001 & 6,948 \\
\hline Deposits & $-82,543$ & $-101,719$ & $-103,258$ & $-101,719$ & $-103,258$ & $-116,032$ & $-116,284$ & $-126,802$ \\
\hline Credit to private sector & 69,917 & 79,136 & 75,635 & 79,796 & 76,294 & 82,924 & 83,212 & 100,072 \\
\hline Other items net & 12,666 & $\mid 5,801$ & 10,353 & 11,118 & 10,103 & 11,369 & 10,103 & 10,103 \\
\hline Broad maney & 38,650 & 40,809 & 40,630 & 41,482 & 41,304 & 42,176 & 42,898 & 46,954 \\
\hline Currency in circulation & 6,688 & 7,062 & 6,740 & 6,696 & 6,375 & 7,298 & 7,423 & 8,125 \\
\hline Demand deposits & 21,033 & $\ldots$ & 21,958 & $\ldots$ & 22,794 & $\ldots$ & $\ldots$ & $\ldots$ \\
\hline Time and savings deposits & 10,929 & $\ldots$ & 11,932 & $\ldots$ & 12,135 & $\ldots$ & $\ldots$ & $\ldots$ \\
\hline \multicolumn{9}{|l|}{ Memorandum items: } \\
\hline Reserve money 4/ & 5.4 & 5.6 & 6.3 & 5.6 & 6.3 & 2.4 & 11.0 & 9.5 \\
\hline Broad money $4 /$ & 17.3 & 5.6 & 5.1 & 7.3 & 6.9 & 13.9 & 11.0 & 9.5 \\
\hline Credit to private sector $4 /$ & 17.0 & 13.2 & 8.2 & 14.1 & 9.1 & 16.5 & 19.0 & 20.3 \\
\hline Private deposits at banks 4 / & 20.4 & $\ldots$ & 6.0 & $\ldots$ & 9.3 & $\ldots$ & $\ldots$ & $\ldots$ \\
\hline Government deposits at banks $4 /$ & 27.5 & 45.7 & 24.9 & 45.7 & 24.9 & 55.6 & 48.9 & 63.3 \\
\hline Money multiplier & 4.0 & 3.98 & 3.93 & 4.04 & 4.00 & 4.0 & 4.0 & 4.0 \\
\hline Velocity of broad money & 6.34 & 6.34 & 6.37 & 6.34 & 6.26 & 6.34 & 6.34 & 6.34 \\
\hline Outstanding treasury bills/bonds & 18,697 & $\ldots$ & 18,787 & ... & 18,887 & $\ldots$ & $\ldots$ & $\ldots$ \\
\hline Issued for bank restructuring & 12,547 & $\ldots$ & 12,547 & $\ldots$ & 12,547 & $\ldots$ & $\ldots$ & $\ldots$ \\
\hline Issued through auction & 6,150 & $\ldots$ & 6,240 & $\ldots$ & 6,340 & $\ldots$ & $\ldots$ & $\cdots$ \\
\hline \multicolumn{9}{|l|}{ Of which: } \\
\hline To banks & 5,950 & $\ldots$ & 6,070 & $\ldots$ & 6,170 & $\ldots$ & $\ldots$ & $\cdots$ \\
\hline To nonbanks & 200 & $\ldots$ & 170 & $\ldots$ & 170 & $\ldots$ & $\ldots$ & $\ldots$ \\
\hline Average auctioned -bill rate (in percent) & 3.75 & $\cdots$ & 6.57 & $\cdots$ & 6.57 & $\cdots$ & $\cdots$ & $\cdots$ \\
\hline
\end{tabular}

Sources: Mauritanian authorities; and Fund staff estimates.

1/ Based on an exchange rate of US\$1 $=265.5$ ouguiyas.

2/ Adjusted starting from June 2002 to take into account the addition of a new commercial bank.

$3 /$ Based on an exchange rate of US $\$ 1=280.0$ ouguiyas.

4/ Year-on-year growth. 
Table 5. Mauritania: Performance Criteria and Structural Benchmarks for 2002

\begin{tabular}{|c|c|c|c|}
\hline & Structural Measures & Timetable & Status \\
\hline A. & Performance Criteria & & \\
\hline 1. & $\begin{array}{l}\text { Identify and classify all budgetary expenditures associated with poverty reduction } \\
\text { in accordance with the new (functional) nomenclature }\end{array}$ & September 2002 & Met \\
\hline 2. & $\begin{array}{l}\text { Draw up medium-term expenditure frameworks for the remaining priority sectors } \\
\text { (road infrastructure, rural development, and urban development) }\end{array}$ & June 2002 & Met \\
\hline $\begin{array}{l}3 . \\
4 .\end{array}$ & $\begin{array}{l}\text { Appoint auditors for the } 2001 \text { financial year through a formal and transparent selection process } \\
\text { Publish the audited financial statements and audit opinion for } 2001 \text { with the objective of } \\
\text { incrcasing the transparency of central bank operations }\end{array}$ & September 2002 & Not met $\mathrm{l} /$ \\
\hline B. & Struetural Benchmarks & & \\
\hline 1. & Issue a circular on the 3 percent remuneration on public deposits with commercial banks & February 2002 & Met \\
\hline 2. & $\begin{array}{l}\text { Adopt the law organizing the distribution of petroleum products and guaranteeing unrestricted } \\
\text { entry into the sector }\end{array}$ & March 2002 & Met \\
\hline 3. & Complete the report on transferring public deposits with commercial banks to the central bank & June 2002 & Met \\
\hline
\end{tabular}

1/ This was observed on November 12, 2002. 
Table 6. Mauritania: Quarterly Quantitative Benchmarks and Performance Criteria for 2002 1/

\begin{tabular}{|c|c|c|c|c|c|c|c|c|c|c|}
\hline & \multirow{3}{*}{$\frac{\text { Dec-01 }}{\text { Beginning }}$} & \multicolumn{3}{|c|}{$\begin{array}{l}\text { Quantitative } \\
\text { Benchmark }\end{array}$} & \multirow{2}{*}{\multicolumn{3}{|c|}{$\begin{array}{c}\text { Quantitative } \\
\text { Performance Critcria } \\
\text { Jun- } 02 \\
\end{array}$}} & \multicolumn{3}{|c|}{$\begin{array}{l}\text { Quantifative } \\
\text { Benchmark }\end{array}$} \\
\hline & & & Mar-02 & & & & & \multirow{2}{*}{$\frac{\text { Sep-02 }}{\text { Target }}$} & \multirow{2}{*}{$\begin{array}{r}\text { Dec-02 } \\
\text { Target }\end{array}$} & \multirow{2}{*}{ Dec- 02} \\
\hline & & Target & $\begin{array}{r}\text { Adjusted } \\
\text { Target }\end{array}$ & Actual & Target & $\begin{array}{l}\text { Adjusted } \\
\text { Target }\end{array}$ & Actual & & & \\
\hline & \multicolumn{10}{|c|}{ (In millions of ouguiyas) } \\
\hline $\begin{array}{l}\text { Ceiling on net domestic assets of the } \\
\text { central bank }\end{array}$ & $-14,527$ & $-15,587$ & $-19,016$ & $-21,745$ & $-12,723$ & $-11,658$ & $-17,523$ & $-34,781$ & $-27,154$ & $-41,681$ \\
\hline \multirow[t]{2}{*}{ Net domestic financing of the budget } & $\ldots$ & $-17,315$ & $-20,936$ & $-21,060$ & $-20,342$ & $-20,173$ & $-20,925$ & $-13,506$ & $-35,472$ & $\ldots$ \\
\hline & \multicolumn{10}{|c|}{ (In millions of U.S. dollars) } \\
\hline $\begin{array}{l}\text { New nonconcessional external debt } \\
\text { contracted or guarantecd by the } \\
\text { govermment or the central bank }\end{array}$ & 7.9 & 0.0 & 0.0 & 0.0 & 0.0 & 0.0 & 0.0 & 0.0 & 0.0 & 7.9 \\
\hline $\begin{array}{l}\text { Ceiling on the accumulation of new arrears } \\
\text { on public or publicly-guaranteed } \\
\text { extemal debt (continuous) }\end{array}$ & $\ldots$ & 0.0 & 0.0 & 0.0 & 0.0 & 0.0 & 0.0 & 0.0 & 0.0 & $\ldots$ \\
\hline Net international reserves of the central bank & 91.3 & 60.4 & 73.4 & 83.9 & 50.0 & 46.0 & 68.3 & 134.0 & 106.3 & 197.6 \\
\hline Memorandum items: & \multicolumn{10}{|c|}{ (In millions of ouguiyas) } \\
\hline Reserve money & 9,723 & 461 & 461 & 324 & 543 & 543 & 615 & 801 & 1,069 & 10,792 \\
\hline Tax revenues & $\ldots$ & 8,097 & 8,097 & 8,472 & 18,167 & 18,167 & 18,891 & 26,365 & 38,535 & $\ldots$ \\
\hline
\end{tabular}

Sources: Mauritanian authorities; and Fund staff estimates.

1/ For definitions of variables and adjusters, see the Fifth Review's Technical Memorandum of Understanding (TMU) (May 7, 2002). Targets are set on the basis of cumulative flows from the beginning of the year; unless otherwise stated. 
Table 7. Mauritania: Macroeconomic Framework, 1999-2006

(In percent of GDP; unless otherwise indicated)

\begin{tabular}{|c|c|c|c|c|c|c|c|c|c|}
\hline & 1999 & 2000 & $\frac{\text { Actual } 1 /}{2001}$ & $\frac{\text { Prog. 1/ }}{200}$ & $\frac{\text { Rev. Proj. } 1 /}{2}$ & 2003 & 2004 & 2005 & 2006 \\
\hline \multicolumn{10}{|l|}{ Economic growth and prices } \\
\hline Real GDP (percentage change) & 5.2 & 5.2 & 4.6 & 5.1 & 4.2 & 5.3 & 5.7 & 6.0 & 6.3 \\
\hline Nominal GDP (percentage change) & 9.2 & 11.1 & 9.8 & 8.9 & 7.9 & 9.5 & 9.5 & 9.8 & 10.1 \\
\hline GDP implicit deflator (percentage change) & 3.8 & 5.7 & 5.0 & 3.6 & 3.6 & 4.0 & 3.6 & 3.6 & 3.5 \\
\hline $\begin{array}{l}\text { Consumer price index (annual percentage change, } \\
\text { period average) }\end{array}$ & 4.1 & 3.3 & 4.7 & 4.0 & 4.0 & 4.0 & 3.7 & 3.5 & 3.5 \\
\hline Gross domestic expenditures & 110.9 & 111.5 & 112.3 & 118.6 & 118.6 & 123.0 & 122.2 & 122.1 & 122.8 \\
\hline $\begin{array}{l}\text { Consumption } \\
\text { Government } \\
\text { Nongovernment } 2 \text { f }\end{array}$ & $\begin{array}{l}93.8 \\
14.8 \\
79.0\end{array}$ & $\begin{array}{l}82.9 \\
16.9 \\
66.1\end{array}$ & $\begin{array}{l}86.3 \\
15.2 \\
71.0\end{array}$ & $\begin{array}{l}94.0 \\
18.4 \\
75.6\end{array}$ & $\begin{array}{l}94.1 \\
18.2 \\
75.8\end{array}$ & $\begin{array}{l}97.0 \\
18.7 \\
78.4\end{array}$ & $\begin{array}{l}95.6 \\
18.8 \\
76.8\end{array}$ & $\begin{array}{l}95.1 \\
18.0 \\
77.1\end{array}$ & $\begin{array}{l}95.5 \\
18.1 \\
77.4\end{array}$ \\
\hline $\begin{array}{l}\text { Gross flxed finvestment } \\
\text { Government } \\
\text { Nongovernment } 2 / 3 / \\
\text { Private }\end{array}$ & $\begin{array}{r}17.1 \\
5.6 \\
11.5 \\
5.6\end{array}$ & $\begin{array}{r}28.6 \\
7.4 \\
21.2 \\
10.2\end{array}$ & $\begin{array}{r}26.0 \\
8.1 \\
17.9 \\
10.0\end{array}$ & $\begin{array}{r}24.7 \\
11.9 \\
14.1 \\
9.3\end{array}$ & $\begin{array}{r}24.6 \\
10.6 \\
14.0 \\
8.7\end{array}$ & $\begin{array}{r}26.0 \\
11.9 \\
14.1 \\
9.3\end{array}$ & $\begin{array}{l}26.6 \\
12.4 \\
14.2 \\
10.1\end{array}$ & $\begin{array}{l}27.0 \\
12.4 \\
14.6 \\
10.7\end{array}$ & $\begin{array}{l}27.4 \\
12.5 \\
14.9 \\
11.3\end{array}$ \\
\hline $\begin{array}{l}\text { Gross national savings } \\
\text { Government } \\
\text { Nongovemment } 2 /\end{array}$ & $\begin{array}{r}21.2 \\
9.8 \\
11.4\end{array}$ & $\begin{array}{r}29.4 \\
4.6 \\
24.8\end{array}$ & $\begin{array}{r}23.9 \\
2.5 \\
21.4\end{array}$ & $\begin{array}{l}28.5 \\
16.9 \\
11.5\end{array}$ & $\begin{array}{l}33.9 \\
17.0 \\
16.8\end{array}$ & $\begin{array}{r}22.3 \\
8.5 \\
13.9\end{array}$ & $\begin{array}{r}22.7 \\
8.6 \\
14.2\end{array}$ & $\begin{array}{r}22.7 \\
8.9 \\
13.8\end{array}$ & $\begin{array}{r}21.9 \\
7.5 \\
14.4\end{array}$ \\
\hline Current account (inclnding official transfers) & 4.1 & 0.8 & -2.2 & 3.8 & 9.3 & -3.7 & -3.9 & -4.3 & -5.5 \\
\hline $\begin{array}{l}\text { Net exports of goods and services } \\
\text { Exports of goods and services } \\
\text { Imports of goods and services } \\
\text { Net factor income } \\
\text { Net transfers }\end{array}$ & $\begin{array}{r}-10.9 \\
36.8 \\
47.8 \\
2.4 \\
12.6\end{array}$ & $\begin{array}{r}-11.5 \\
39.6 \\
51.2 \\
2.0 \\
10.3\end{array}$ & $\begin{array}{r}-12.3 \\
38.9 \\
51.3 \\
-2.3 \\
12.5\end{array}$ & $\begin{array}{r}-18.6 \\
37.8 \\
56.4 \\
13.5 \\
8.9\end{array}$ & $\begin{array}{r}-18.6 \\
36.7 \\
55.3 \\
14.8 \\
13.1\end{array}$ & $\begin{array}{r}-23.0 \\
36.6 \\
59.6 \\
6.8 \\
12.6\end{array}$ & $\begin{array}{r}-22.2 \\
37.0 \\
59.3 \\
6.8 \\
11.6\end{array}$ & $\begin{array}{r}-22.1 \\
37.0 \\
59.1 \\
6.7 \\
11.0\end{array}$ & $\begin{array}{r}-22.8 \\
36.8 \\
59.7 \\
6.0 \\
11.3\end{array}$ \\
\hline \multicolumn{10}{|l|}{ Memorandum itern: } \\
\hline $\begin{array}{l}\text { Nominal GDP (in billions of ouguiyas) } \\
\text { Govemment revenue, excluding grants }\end{array}$ & $\begin{array}{r}206.5 \\
27.1\end{array}$ & $\begin{array}{r}229.4 \\
25.3\end{array}$ & $\begin{array}{r}252.0 \\
20.6\end{array}$ & $\begin{array}{r}267.3 \\
37.1\end{array}$ & $\begin{array}{r}271.9 \\
37.2\end{array}$ & $\begin{array}{r}297.6 \\
29.3\end{array}$ & $\begin{array}{r}326.0 \\
28.4\end{array}$ & $\begin{array}{r}358.0 \\
27.7\end{array}$ & $\begin{array}{r}394.2 \\
26.1\end{array}$ \\
\hline Government expenditures & 25.0 & 29.6 & 26.0 & 30.8 & 30.9 & 31.6 & 31.6 & 31.2 & 31.0 \\
\hline Overall government balance & 2.1 & -4.4 & -5.5 & 6.3 & 6.3 & -2.3 & -3.1 & -3.5 & -5.0 \\
\hline
\end{tabular}

Sources: Mauritanian authorities; and Fund staff estimates and projections.

1/ The delayed payment of the 2001 fish royalties explains the uncven movements in gross national saving, government balance and saving, the current account, and net factor income.

2/ Includes SNIM and olher public enterpises.

3/ The decline in the share of nongovernment investment to GDP reflects the decline in public enterprises' share, which is partially oflset by the increase in private sector investment share over the period $2000-05$. 
Table 8. Mauritania: The Change in Banking Prudential Indicators Between end-December 2001 and end-June 2002 1/

\begin{tabular}{|c|c|c|c|c|c|c|}
\hline & \multicolumn{3}{|c|}{ End-December 2001} & \multicolumn{3}{|c|}{ End-June 2002} \\
\hline & $\begin{array}{c}\text { Liquidity ratio } \\
\text { (over } 20 \% \text { ) }\end{array}$ & $\begin{array}{l}\text { Capital adequacy } \\
\text { ratio (over } 10 \% \text { ) }\end{array}$ & $\begin{array}{l}\text { Ratio of fixed assets } \\
\text { to capital (under } 100 \% \text { ) }\end{array}$ & $\begin{array}{l}\text { Liquidity ratio } \\
\text { (over } 20 \% \text { ) }\end{array}$ & $\begin{array}{l}\text { Capital adequacy } \\
\text { ratio (over 10\%) }\end{array}$ & $\begin{array}{c}\text { Ratio of fixed assets } \\
\text { to capital (under } 100 \% \text {; }\end{array}$ \\
\hline Bank 1 & $22.4 \%$ & $15.4 \%$ & $98.4 \%$ & $22.5 \%$ & $13.8 \%$ & $108.2 \%$ \\
\hline Bank 2 & $20.7 \%$ & $22.5 \%$ & $46.5 \%$ & $21.2 \%$ & $23.2 \%$ & $47.5 \%$ \\
\hline Bank 3 & $43.8 \%$ & $27.5 \%$ & $60.7 \%$ & $46.0^{\circ} \%$ & $26.1 \%$ & $60.5 \%$ \\
\hline Bank 4 & $36.2 \%$ & $20.0 \%$ & $55.9 \%$ & $22.5 \%$ & $17.8 \%$ & $65.4 \%$ \\
\hline Bank 5 & $30.9 \%$ & $14.2 \%$ & $68.3 \%$ & $29.8 \%$ & $14.0 \%$ & $68.6 \%$ \\
\hline Bank 6 & $29.3 \%$ & $20.1 \%$ & $66.2 \%$ & $24.4 \%$ & $19.1 \%$ & $73.3 \%$ \\
\hline Bank 7 & $22.0 \%$ & $18.8 \%$ & $73.7 \%$ & $23.0 \%$ & $15.5 \%$ & $77.5 \%$ \\
\hline \multirow[t]{4}{*}{ Bank 8} & $\cdots$ & $\ldots$ & $\ldots$ & $82,6 \%$ & $55.5 \%$ & $43.0 \%$ \\
\hline & \multicolumn{6}{|c|}{ Concentration of group borrowers } \\
\hline & \multicolumn{3}{|c|}{ End-December 2001} & \multicolumn{3}{|c|}{ End-Jure 2002} \\
\hline & Target $2 /$ & Status 3/ & No. of groups > target & Target $2 \prime$ & Status 3I & No. of groups $>$ target \\
\hline Bank 1 & $62.5 \%$ & $103.2 \%$ & & $60.0 \%$ & $54.8 \%$ & 0 \\
\hline Bank 2 & $62.5 \%$ & $63.7 \%$ & 1 & $60.0 \%$ & $58.8 \%$ & 0 \\
\hline Bank 3 & $62.5 \%$ & $76.5 \%$ & 1 & $60.0 \%$ & $57.6 \%$ & 0 \\
\hline Bank 4 & $47.5 \%$ & $2.10 \%$ & 0 & $40.0 \%$ & $20.4 \%$ & 0 \\
\hline Bank 5 & $47.5 \%$ & $13.1 \%$ & 0 & $40.0 \%$ & $12.8 \%$ & 0 \\
\hline Bank 6 & $47.5 \%$ & $23.9 \%$ & 0 & $40.0 \%$ & $26.4 \%$ & 0 \\
\hline Bank 7 & $47.5 \%$ & $55.8 \%$ & 1 & $40.0 \%$ & $38.5 \%$ & 0 \\
\hline \multirow[t]{4}{*}{ Bank 8} & $\ldots$ & $\cdots$ & $\ldots$ & $\ldots$ & $\ldots$ & $\ldots$ \\
\hline & \multicolumn{6}{|c|}{ Concentration of individual bortowers } \\
\hline & \multicolumn{3}{|c|}{ End-December 2001 } & \multicolumn{3}{|c|}{ End-June 2002} \\
\hline & Target $2 /$ & Status $3 /$ & No. of groups $>$ target & Target $2 /$ & Status 3/ & No. of groups $>$ target \\
\hline Bank 1 & $35 \%$ & $57.4 \%$ & 2 & $32.5 \%$ & $22.1 \%$ & 0 \\
\hline Bank 2 & $35 \%$ & $35.9 \%$ & 1 & $32.5 \%$ & $30.1 \%$ & 0 \\
\hline Bank 3 & $35 \%$ & $62.1 \%$ & 3 & $32.5 \%$ & $26.5 \%$ & 0 \\
\hline Bank 4 & $25 \%$ & observed $4 /$ & 0 & $20 \%$ & observed 4 f & 0 \\
\hline Bank 5 & $25 \%$ & observed $4 /$ & 0 & $20 \%$ & observed $4 /$ & 0 \\
\hline Bank 6 & $25 \%$ & observed $4 /$ & 0 & $20 \%$ & observed $4 /$ & 0 \\
\hline Bank 7 & $25 \%$ & $23.8 \%$ & 0 & $20 \%$ & $15.3 \%$ & 0 \\
\hline Baлk 8 & $\ldots$ & $\ldots$ & $\cdots$ & $\cdots$ & $\cdots$ & $\ldots$ \\
\hline
\end{tabular}

Source: Mauritanian authorities.

1/ The prudential framework's compliance with the 25 Basle core principles was last assessed in late 1999 by MAE. It was found that there was broad compatiblity with 11 principles; suggestions for specific improvements in application and monitoring with 13 principles; and a serious shortcoming with one principle, which is the subject of the current directive revision (asset quality and provisioning). Some of these have been addressed through the current contrats programmes. However, the ratio of fixed assets to capital exceeds the Basle 75 percent maximum.

2f These ratios are set bi-annualiy in the contrats programmes and are due to continue in a downward trend until end-2004 to bring all banks to 10 percent and 25 percent concentration to individual and group borrowers, respectively.

3/ The highest concentration ratio registered.

4/ Details are unavailable. 
Table 9. Mauritania: Quarterty Quantitative Benchmarks for $20031 /$

\begin{tabular}{|c|c|c|c|c|c|c|}
\hline & $\begin{array}{l}\text { Beginning } \\
\text { Stock } \\
\end{array}$ & Target & Target & Target & Target & End Stock \\
\hline & Dec- -92 & Mar-03 & Jun-03 & Sep-03 & Dee- 03 & Dee-03 \\
\hline & \multicolumn{6}{|c|}{ (In millions of ouguiyas) } \\
\hline $\begin{array}{l}\text { Ceiling on net domestic assets of the } \\
\text { central bank }\end{array}$ & $-44,547$ & 7,316 & 15,832 & -229 & 2,809 & $-41,738$ \\
\hline \multirow[t]{2}{*}{ Net domestic tinancing of the budget } & $\cdots$ & 3,854 & 6,346 & $-8,468$ & $-14,07 \mathrm{I}$ & $\cdots$ \\
\hline & \multicolumn{6}{|c|}{ (In millions of U.S. dollars) } \\
\hline $\begin{array}{l}\text { New nonconcessional extemal debt } \\
\text { contracted or guaranteed by the } \\
\text { government or the central bank }\end{array}$ & 7.9 & 0.0 & 0.0 & 0.0 & 0.0 & 7.9 \\
\hline $\begin{array}{l}\text { Ceiling on the accumulation of new arrears } \\
\text { on public or publicly-guaranteed } \\
\text { external debt (continuous) }\end{array}$ & $\cdots$ & 0.0 & 0.0 & 0.0 & 0.0 & $\ldots$ \\
\hline Net international reserves of the central bank & 197.6 & -24.7 & -54.7 & 3.5 & -6.4 & -6.4 \\
\hline \multicolumn{7}{|l|}{ Mernorandum items: } \\
\hline & \multicolumn{6}{|c|}{ (In millions of ouguiyas) } \\
\hline Reserve money & 10,792 & 388 & 510 & 765 & 1,020 & 11,812 \\
\hline Tax revenues & $\ldots$ & 8,836 & 19,871 & 29,120 & 42,557 & $\ldots$ \\
\hline
\end{tabular}

Sources: Mauritarian authorities; and Fund staff estimates.

1/ For definitions of variables and adjusters, see the Fifth Review's Technical Memorandum of Understanding (TMU) (May 7, 2002). Targets are set on the basis of cumulative flows from the beginning of the year; unless othervise stated. 


\section{Mauritania: Fund Relations}

As of September 30, 2002

I. Membership Status: Joined: 09/10/1963; Article VIII

II. General Resources Account:

Quota

Fund holdings of currency

III. SDR Department:

Net cumulative allocation

Holdings

IV. Outstanding Purchases and Loans:

ESAF/PRGF Arrangements

V. Latest Financial Arrangements:

Type Approva]

Expiration

ESAF/PRGF

Date

ESAF

$07 / 21 / 1999$

Date

$01 / 25 / 1995$

$12 / 20 / 2002$

$07 / 13 / 1998$

12/09/1992

ESAF

$01 / 24 / 1995$ $\underline{\text { SDR Million }}$

64.40

64.41

$\underline{\text { SDR Million }}$

9.72

0.00

SDR Million

79.10
$\%$ Quota

100.00

100.01

$\%$ Allocation

100.0

0.09

$\%$ Quota

122.82
Amount Approved

(SDR Million)

42.49

42.75

33.90
Amount Drawn

(SDR Million)

36.42

42.75

33.90

\section{Projected Payments to Fund}

Without HIPC Assistance

(SDR million; based on existing use of resources and present holdings of SDRs):

\begin{tabular}{lrrrrr} 
& & \multicolumn{5}{c}{ Forthcoming } \\
\cline { 5 - 7 } & $\underline{2002}$ & $\underline{2003}$ & $\underline{2004}$ & $\underline{2005}$ & $\frac{2006}{9.66}$ \\
Chincipal & 2.27 & 13.64 & 11.09 & 9.63 \\
Total & $\underline{0.25}$ & $\underline{0.56}$ & $\underline{0.50}$ & $\underline{0.45}$ & $\underline{0.41}$ \\
Total Interest & $\underline{14.19}$ & $\underline{11.59}$ & $\underline{10.11}$ & $\underline{9.04}$
\end{tabular}

With Board-approved HIPC Assistance

(SDR million; based on existing use of resources and present holdings of SDRs):

Forthcoming

Principal

$2002 \quad \frac{2003}{6.03} \quad \frac{2004}{6.87} \quad \frac{2005}{6.49} \quad \frac{2006}{5.39}$

Charges/Interest

Total

\begin{tabular}{|c|c|c|c|}
\hline 25 & 0.56 & 0.50 & 0.45 \\
\hline 0.2 & & 7.37 & 6.94 \\
\hline
\end{tabular}




\section{Implementation of HIPC Initiative}

I. Commitment of HIPC assistance

Decision point date

Enhanced

Assistance committed

Framework

Feb. 2000

By all creditors (US\$ million) ${ }^{1}$

622.00

Of which: IMF assistance (US\$ million)

46.76

(SDR equivalent in millions)

34.80

Completion point date

June 2002

II. Disbursement of IMF assistance (SDR million)

Assistance disbursed to the member

Interim assistance

Completion point balance

Additional disbursement of interest income ${ }^{2}$

Total disbursements

\section{Safeguards Assessments}

Under the Fund's safeguards assessment policy, the Banque Centrale de Mauritanie (BCM) is subject to the transitional procedures with respect to the PRGF Arrangement, which was approved on July 21, 1999, and is scheduled to expire on December 20, 2002. The transitional procedures require a review of only the BCM's external audit mechanism. This assessment determines whether the BCM publishes annual financial statements that are independently audited in accordance with internationally accepted standards. The assessment concluded that the BCM's current external audit mechanism may not be adequate in certain respects, and appropriate recommendations have been made to the authorities, as reported in the Staff Report for the 2002 Article IV Consultation and the Fifth Review Under the Poverty Reduction and Growth Facility, and Request for Waivers of Performance Criteria.

\section{Exchange and Trade Arrangements}

Mauritania is following a managed floating exchange rate regime and is free of exchange restrictions and multiple currency practices. During the period from January 1974 to December 1995, the official exchange rate of the ouguiya was determined on the basis of a basket of currencies. On December 31, 1995, the official and the free market exchange rates

\footnotetext{
${ }^{\mathrm{L}}$ Assistance committed under the original framework is expressed in net present value (NPV) terms at the completion point, and assistance committed under the enbanced framework is expressed in NFV terms at the decision point.

${ }^{2}$ Under the enlanced HIPC Initiative, an additional disbursement is made at the completion point corresponding to interest income eamed on the amount committed at the decision point but not disbursed during the interim period.
} 
were unified, and official transactions were effected at the average exchange rate in the free market. At end-July 1997, the authorities adopted a more active exchange rate policy. And, beginning November 1998, the central bank maintained a weekly announced official exchange rate at which it sold/bought any quantity required to clear the market. On April 17, 2000, Mauritania introduced the Extended Exchange Market (EEM), unifying different components of the official exchange market. The rate fixed in the daily sessions of this market is then announced by the BCM as the official exchange rate for the following day. On August 4, 2002, the BCM issued two circulars: the first sets limits on, and regulates, the handling of foreign bank notes and the second reimposes a variant of a surrender requirement where 70 percent of fishing export receipts should be repatriated via the BCM. On October 17, 2002, US\$1 was equivalent to UM 270.4 .

\section{Last Article IV Consultation}

Mauritania is on the standard 12-month cycle for Article IV consultations.

Discussions for the 2002 Article IV consultation were held in Nouakchott during January 29February 12, 2002. The staff report (May 07, 2002) was considered by the Executive Board on June 7, 2002. The Executive Board approved the HIPC Completion Point document for Mauritania (May 10, 2002) on June 7, 2002.

XI. FSAP Participation, ROSCs and Offshore Financial Center (OFC) Assessments:

A Preliminary Report on the Observance of Standards and Codes (ROSC) was based on two missions, respectively conducted from May 14 to 24, 2002 and from August 6 to 13, 2002. The final ROSC report is due soon.

\section{Technical Assistance (since 1998)}

1. MAE

a. Money and banking

Technical assistance missions on strengthening the functioning of the treasury bill market: March 8-22 and June 8-14, 1998.

Technical assistance mission on deepening of financial sector reforms and strengthening of the financial system: February 18-March 3, 1999.

Technical assistance mission on monetary instruments: May 6-20, 2000.

Technical assistance mission on money market development and reform of monetary instruments: September 30-October 10, 2000.

Follow-up mission on reform of monetary instruments and assessment of technical assistance needs: February 7-20, 2001. 
Resident expert on banking supervision: August 1, 2001-August 1, 2002.

Resident expert on banking supervision: August 3, 2002-February 2, 2003.

b. Exchange system

Bi-monthly visits by panel expert on the reform of the exchange system:

December 1992-present.

Advisor to the $\mathrm{BCM}$ governor on the development of foreign exchange market and related operations: May 1999-April 2000.

c. Other

Advisor to the Govemor: May 1994-February 2000.

2. FAD

Technical assistance mission on budget nomenclature: July 15-26, 1998.

Technical assistance mission on reinforcing fiscal administration and improving VAT performance: April 25-May 9, 1999.

Long-term resident technical advisor on tax administration and tax system reform for six months beginning April 25, 2000, extended by government requests until April 24, 2001.

Technical assistance mission on tracking of execution of poverty-reducing expenditures, October 10-17, 2001.

Follow-up mission on improving VAT performance: November 10-17, 2000.

TA mission on tracking poverty-related expenditure: October 10-17, 2001.

TA mission on setting up a VAT refund system: November 18-23, 2001.

3. STA

Technical assistance mission on national accounts: November 8-22, 1997.

Technical assistance mission on balance of payments statistics: August 30September 9, 1999.

Technical assistance mission on monetary statistics: January 9-22, 2002, 
XIII. Resident Representative

A resident representative (Mr. Prosper Youm) took position in Nouakchott in April 2001. 


\section{Mauritania: World Bank Relations}

\section{Partnership in Mauritania's Development Strategy}

1. The Mauritanian government's development strategy is set forth in the Poverty Reduction Strategy Paper (PRSP), approved in early 2001. The PRSP focuses on four pillars: (i) stimulating accelerated and redistributive growth; (ii) anchoring growth in the economic environment of the poor; (iii) developing human resources and ensuring universal access to basic infrastructure and services; and (iv) strengthening institutional capacities and governance. In June 2002, Mauritania presented its first PRSP Progress Report (PRSP-PR), reviewing first-year implementation of the PRSP. The next PRSP-PR will be presented to the Boards of the World Bank and IMF in the first quarter of 2003. The next PRSP is due in 2005.

2. The World Bank and the IMF will continue to cooperate closely in assisting the government of Mauritania to implement its medium-term poverty reduction strategy, as presented in the PRSP and updated in the PRSP-PR, with each institution taking the policy dialogue lead in its areas of expertise.

3. The Fund will continue to lead the policy dialogue on macroeconomic policy (fiscal, monetary, and exchange rate policies) and in the following areas of structural reforms: fiscal management and control, banking supervision and banking sector issues, pension reform, and tax reform. The Bank will contimue to lead the policy dialogue on other structural reforms, including privatization and poverty monitoring and evaluation. Areas of close collaboration include the PRSP, public expenditure management, external debt sustainability, and poverty and social impact analysis. The Bank and the Fund also routinely exchange views on tax reform, private sector development, and financial sector reform.

\section{Bank Group Strategy}

4. The World Bank supports the implementation of the PRSP through its Country Assistance Strategy (CAS, FY02-04). ${ }^{1}$ The following strategic elements are pursued in the CAS: (i) the program of lending and nonlending operations has been specifically designed to support implementation of the four strategic axes of the PRSP; (ii) capacity building is the main emphasis of the CAS; (iii) the focus of the Bank's lending program will be through programmatic support through three Poverty Reduction Support Credits (PRSC); (iv) fiduciary issues are fully taken into account within the scope and sequencing of the PRSCs; and (v) the shift to programmatic lending through the PRSCs will be underpinned by the Bank's core diagnostic ESW.

\footnotetext{
'The CAS base- and high-case lending scenarios assume a lending level of US $\$ 110$ million and US $\$ 140$ million, respectively.
} 
5. While a series of PRSCs would be the main pillar of the lending program, the shift from traditional investment lending to programmatic lending will be phased in gradually. During the CAS period, the Bank will continue with selected investment projects targeting poverty reduction, institutional strengthening, and capacity building. To date, the World Bank Group has approved 64 loans and credits for Mauritania for a total of US\$857.5 million. The current project portfolio consists of 13 investment operations for a total commitment of US\$294 million with an undisbursed balance of US\$184.4 million. The Bank's lending operations reflect a cross-sectoral emphasis on accelerating diversified and private sector-led growth and reducing poverty.

6. The Bank's portfolio supports projects to improve the living conditions of the population in both urban and rural areas. An Urban Development Program (US\$17.0 million-FY02) supports Mauritania's central and local governments to promote employment opportunities in the main urban centers, focusing in particular on slums. The project also aims at strengthening the institutional framework and technical capacity for urban and land management at the central and municipal levels. Two projects support Mauritania's rural development strategy. The Rainfed Natural Resources Management Project (US\$18 million-approved in June 1997) aims at contributing to break the poverty spiral of population growth, environmental degradation, and low agricultural productivity. The Integrated Development Program for Irrigated Agriculture in Mauritania (PDIAIMJuly 1999) aims at increasing agriculture's value-added, and income and employment opportunities for the population living in the Senegal River Valley.

7. In the social sectors, the World Bank Group's assistance is geared towards supporting Mauritania's strategy to improve the access to, and quality of, basic services in health and education. The Bank's portfolio in education comprises three projects. The General Education Project (US\$35 million-April 1995) supports the overall strategy in the sector. The Education Development Program (US\$49.2 million - FY02) aims at improving access and equity in primary and secondary education. The Global Distance-Learning Center Project (US\$3.3 million-FY02) seeks to develop international knowledge-sharing in development issues. In health, a Health Sector Investment Project (US\$24 million-March 1998) supports the implementation of the authorities' sector strategy for the period 1998-2002. In addition, a Nutrition Project (US\$4.9 million-March 1999) assists in testing the effectiveness of various activities to improve mother and child's nutrition status and health.

8. An important part of the Bank's portfolio focuses on strengthening the investment climate and encouraging private sector participation. A Mining Sector Capacity Building Project (US\$15 million-May 1999) aims at strengthening the government's capacity to act as facilitator and regulator of mining activities and increase private investment in Mauritania's mining sector. A Telecommunications Postal Reform Project (US\$10.8 million-June 1999) seeks to help the government extend access to communications and information services at more competitive prices, through establishing a legal, regulatory, and institutional framework favorable to competitive private service provision in these sectors. An Energy Water Sanitation Sector Reform TA credit 
(US\$9.9 million) assists the government in (i) the restructuring of the legal and institutional framework of the water/sanitation and energy sectors to create an environment for private sector participation; and (ii) the preparation of future investments in the water/sanitation and energy sectors (urban and rural).

9. The Bank's portfolio also comprises A Regional Power Project (US\$11.1 millionJune 1997), aiming at increasing the efficiency and reliability of the power systems and at mitigating environmental problems caused by dams; and a Cuttural Heritage LIL (US\$5 million), assisting the government to safeguard and enhance the country's cultural heritage.

\section{Bank-Fund Collaboration in Specific Areas}

10. As part of its overall assistance to Mauritania - through lending, country analytical work, and technical assistance-the Bank supports policy reforms in close collaboration with the Fund, in the following areas:

- Public Expenditure Management. The Fund and Bank jointly emphasize the urgent need to further improve public expenditure management, accountability, and transparency. The two institutions support policy reforms in the areas of budget formulation, execution, and monitoring. On budget formulation, it has been agreed with the authorities that an overall Medium-Term Expenditure Framework (MTEF) will be in place by June 2003 and will be used in the preparation of the 2004 budget. On budget execution, emphasis has been placed on the need to accelerate the execution of expenditure, notably in social sectors, modernization of the public procurement system, and expediting the computerization of expenditure. On budget reporting, the Bank and Fund will support Mauritania in its efforts to strengthen the capacity of audit institutions and produce budget execution laws in a timely fashion. ${ }^{2}$ Other common areas of advice include the need to increase overall absorption capacity and improve the tracking of poverty-related spending, both in the budget and those financed by HIPC resources.

- Maintaining External Debt Sustainability. Mauritania reached its completion point under the enhanced HIPC Initiative in June 2002. As a result, more resources have been freed up to support the government's efforts toward improving the standard of living of the population. Both the Bank and Fund have emphasized the need to improve the authorities ' debt management practices by strengthening the coordination between the departments concerned, building technical capacity and unifying the debt database. In addition, given the country's vulnerability to external shocks, vigilance will be required to ensure that a prudent external policy is pursued.

\footnotetext{
${ }^{2} \mathrm{~A}$ set of recommendations concerning these important topics are elaborated in the reports prepared (or under way) by the IMF and Bank, including: a Country Procurement Assessment Review (WB, 2002), a Report on the Observance of Standard and Codes (IMF, forthcoming 2002), a HIPC Expenditure Tracking Study (Joint IMF/WB, 2002), and a Country Financial Accountability Assessment (WB, forthcoming 2003).
} 
- Financial Sector Reform. As part of the CAS, the Bank, in close collaboration with the Fund, is helping the authorities in restructuring the central bank, improving financial sector intermediation for private sector development, and mobilizing savings, while promoting competition in the financial sector.

- Poverty and Social Impact Analysis (PSIA). As part of the preparation of future Bank structural adjustment lending and the IMF program supported by PRGF Arrangements, the Bank and Fund have agreed to review closely the poverty and social impact of reforms that are being implemented. In particular, given increased allocation of expenditure to social sectors, it has been agreed that a benefit incidence analysis will be conducted in the health and education sectors to assess the welfare impact of public spending on different groups of people. At the same time, PSIA will be conducted on the proposed policy reforms in the water sector. This work will begin by early 2003 and will be carried out by the authorities with the technical assistance of the World Bank.

\section{Contact Persons}

Questions may be addressed to Mr. David Craig, Country Director, at 202-473-2589; or Mr. Nicola Pontara, Economist, at 202-458-0400. 
Mr. Horst Köhler

Managing Director

International Monetary Fund

Washington, D.C. 20431

Dear Mr. Köbler:

The government of Mauritania recently held discussions with International Monetary Fund (IMF) staff on the sixth review of the program supported under the Poverty Reduction and Growth Facility (PRGF).

The government considers that program execution in 2002 is consistent with the established objectives. The quantitative performance criteria and quantitative benchmarks for end-June were met, as were all continuous performance criteria under the arrangement. All the structural performance criteria and benchmarks were also met, except for the criterion concerning the publication of the audited 2001 financial statements of the Central Bank of Mauritania (BCM) and the related audit opinion. This was due to technical reasons related to delays by the external auditors. The $2001 \mathrm{BCM}$ financial statements and related audit opinion were received from the auditors on October 16 (preliminary) and on November 2 (final) and were published on November 12, 2002. The government requests a waiver for the nonobservance of this criterion and the completion of the sixth review of the program supported under the PRGF.

The government wishes to initiate discussions as soon as possible on a program to be supported by a new arrangement under the PRGF. In the context of the discussions with IMF staff, the government has set objectives for 2003 based on the policies established in the Poverty Reduction Strategy Paper (PRSP), especially in the framework of the 2003 budget law. During the coming year, the government intends to pursue its structural reforms, in particular with a view to strengthening the performance of the exchange market, increasing fiscal transparency, improving absorption capacity to speed up the pace of social spending, and rehabilitating the National Social Security Fund (CNSS).

To enhance the performance of the exchange market, the central bank has set up a foreign exchange committee which each day establishes the central bank's intervention policy objectives for the expanded exchange market (MCE). Every moming, the central bank announces an opening buying and selling rate for foreign exchange. At the same time, allthe-market buying and selling orders at "best price" will be eliminated. The central bank is determined to intervene regularly in the foreign exchange market and to place sufficient foreign banknotes at the disposal of authorized intermediaries to ensure that the market performs smoothly. The BCM will also make sure that the commercial banks play their role as an intermediary which, among other things, requires them to provide foreign exchange for all their clients. 
The government is in the process of drafting the budget execution law for 2001, which will be submitted to parliament at the same time as the 2003 budget, and from January 2003, will start regular production of monthly government flow of funds tables (TOFE). The production of the TOFE will be computerized subsequent to the reorganization of the divisions of the treasury (government accounting office) and the computerization of the treasury accounts. The government also intends to strengthen the Inspectorate General of Finances. High priority will be given to computerizing expenditure procedures with the twofold objective of increasing fiscal transparency and improving expenditure tracking. The choice of consultant to take charge of computerizing expenditure on goods and services will be made before the end of the year.

Studies on (i) the reorganization of the CNSS, including the social plan accompanying the reduction of human resources; (ii) the definition of a renewed social protection policy; and (iii) the computerization of the CNSS, will be completed before the end of the first quarter of 2003, and implementation of their conclusions will start in the second quarter of 2003. At the same time, the CNSS is continuing its efforts in the areas of internal reorganization, identification of taxpayers, increased command over the tax base, and investigations to provide a better assessment of entitlement to benefits. Pending the final version of the actuarial study by the ILO, the government will put in place a program in 2003 to alleviate the CNSS's difficult financial situation.

The government is convinced that the implementation of these policies will enable it to meet the agreed objectives. It is understood that the government will remain in contact with Fund staff and will consult the IMF from time to time, on its own initiative or whenever the Managing Director so requests, regarding Mauritania's economic and financial policies.

Sincerely yours,

\author{
$/ \mathrm{s} /$ \\ Yahya Attigh \\ Governor, Central Bank of Mauritania
}

Attachment 
Table 1. Mauritania: Quarterly Quantitative Benchmarks and Performance Criteria for $20021 /$

\begin{tabular}{|c|c|c|c|c|c|c|c|c|c|c|}
\hline & \multirow{4}{*}{$\begin{array}{r}\text { Dec-01 } \\
\text { Beginning } \\
\text { Stock }\end{array}$} & \multicolumn{3}{|c|}{$\begin{array}{r}\text { Quantitative } \\
\text { Benchmark }\end{array}$} & \multicolumn{3}{|c|}{$\begin{array}{l}\text { Quantitative } \\
\text { Performance Criteria }\end{array}$} & \multicolumn{3}{|c|}{$\begin{array}{l}\text { Quantitative } \\
\text { Benchmark }\end{array}$} \\
\hline & & \multicolumn{3}{|c|}{ Mar-02 } & \multicolumn{3}{|c|}{$\operatorname{Jun}=02$} & \multirow{3}{*}{$\begin{array}{r}\text { Sep- } 02 \\
\text { Target }\end{array}$} & \multirow{3}{*}{$\begin{array}{l}\text { Dec-02 } \\
\text { Target }\end{array}$} & \multirow{3}{*}{$\begin{array}{l}\text { Dec-02 } \\
\text { End Stock }\end{array}$} \\
\hline & & & Adjusted & & & Adjusted & & & & \\
\hline & & Target & Target & Actual & Target & Target & Actual & & & \\
\hline & \multicolumn{10}{|c|}{ (In millions of ouguiyas) } \\
\hline $\begin{array}{l}\text { Ceiling on net domestic assets of the } \\
\text { central bank }\end{array}$ & $-14,527$ & $-15,587$ & $-19,016$ & $-21,745$ & $-12,723$ & $-11,658$ & $-17,523$ & $-34,781$ & $-27,154$ & $-41,681$ \\
\hline \multirow[t]{2}{*}{ Net domestic financing of the budget } & $\ldots$ & $-17,315$ & $-20,936$ & $-21,060$ & $-20,342$ & $-20,173$ & $-20,925$ & $-13,506$ & $-35,472$ & $\ldots$ \\
\hline & \multicolumn{10}{|c|}{ (In millions of U.S. dollars) } \\
\hline $\begin{array}{l}\text { New nonconcessional external debt } \\
\text { contracted or guaranteed by the } \\
\text { govermment or the central bank }\end{array}$ & 7.9 & 0.0 & 0.0 & 0.0 & 0.0 & 0.0 & 0.0 & 0.0 & 0.0 & 7.9 \\
\hline $\begin{array}{l}\text { Ceiling on the accumulation of new arrears } \\
\text { on public or publicly-guaranteed } \\
\text { external debt (continuous) }\end{array}$ & $\cdots$ & 0.0 & 0.0 & 0.0 & 0.0 & 0.0 & 0.0 & 0.0 & 0.0 & $\ldots$ \\
\hline Net intemational reserves of the central bank & 91.3 & 60.4 & 73.4 & 83.9 & 50.0 & 46.0 & 68.3 & 134.0 & 106.3 & 197.6 \\
\hline Memorandum items: & \multicolumn{10}{|c|}{ (In millions of ouguiyas) } \\
\hline Reserve money & 9,723 & 461 & 461 & 324 & 543 & 543 & 615 & 801 & 1,069 & 10,792 \\
\hline Tax revenues & $\ldots$ & 8,097 & 8,097 & 8,472 & 18,167 & 18,167 & 18,891 & 26,365 & 38,535 & $\ldots$ \\
\hline
\end{tabular}

Sources: Mauritanian authorities; and Fund staff estimates.

1/ For definitions of variables and adjusters, see the Fifth Review's Technical Memorandum of Understanding (TMU) (May 7, 2002). Targets are set on the basis of cumulative flows from the beginning of the year; unless otherwise stated. 


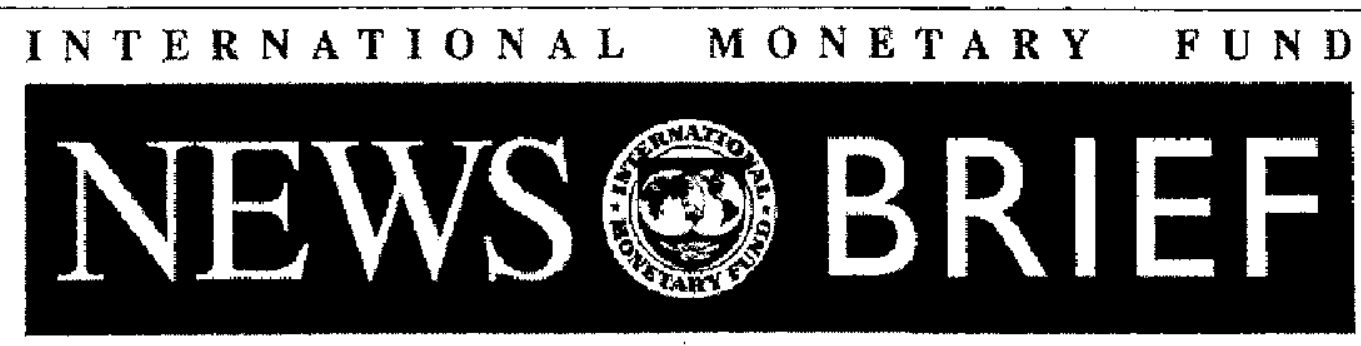

FOR IMMEDIATE RELEASE

News Brief No. 02/119

FOR IMMEDIATE RELEASE

December 4, 2002
International Monetary Fund

70019 th Street, NW

Washington, D. C. 20431 USA

\section{IMF Completes Sixth Review Under Mauritania's PRGF Arrangement and Approves US\$8 Million Disbursement}

The Executive Board of the International Monetary Fund (IMF) today completed the sixth and final review of Mauritania's performance under an economic program supported by the Poverty Reduction and Growth Facility (PRGF). As a result, Mauritania will be able to draw up to SDR 6.07 million (about US\$8 million).

The Board also waived Mauritania's non-observance of the structural performance criterion on the publication of the 2001 Banque Centrale de Mauritanie (Mauritanian Central Bank) audited financial statements and related audit opinion.

Mauritania's three-year arrangement was originally approved on July 21 , 1999 (see Press Release 99/32) under the former Enhanced Structural Adjustment Facility. So far, Mauritania has drawn SDR 36.42 million (about US\$48 million).

The PRGF is the IMF's concessional facility for low income countries. It is intended that PRGF-supported programs are based on country-owned poverty reduction strategies adopted in a participatory process involving civil society and development partners and articulated in a Poverty Reduction Strategy Paper (PRSP). This is intended to ensure that PRGFsupported programs are consistent with a comprehensive framework for macroeconomic, structural, and social policies to foster growth and reduce poverty. PRGF loans carry an annual interest rate of 0.5 percent and are repayable over 10 years with a $51 / 2$-year grace period on principal payments. 
After the Executive Board's discussion on Maunitania, Eduardo Aninat, Deputy Managing Director and Acting Chair, stated:

"The Mauritanian authorities have successfully concluded the current PRGF arrangement, contributing importantly to strong growth, low inflation, and a comfortable level of international reserves-despite a difficult external environment. The authorities have shown strong ownership of the program, and have indicated their intention to maintain a close relationship with the Fund, with a successor program. Mauritania reached its completion point under the enhanced HIPC Initiative in June 2002. Based on the debt relief provided by this Initiative, Mauritania's external debt situation has become more sustainable.

"The key challenges for the future are to reduce external vulnerability by diversifying the economy, and make significant progress in the fight against poverty, as about half of the population continues to live below the poverty line. The authorities are determined to further improve social indicators by strengthening their implementation capacity, and committing the resources freed by debt reduction provided under the HIPC Initiative to essential social spending programs. The success of the child vaccinatton program and improvements in school enrollment indicators give early evidence of the progress being made in these areas.

"The current monetary policy stance is appropriate to keep inflation low. A move toward a more fully market-based credit allocation mechanism would be an important step to enhance transparency and increase intermediation. Efforts by the authorities to improve the functioning of the foreign exchange market would strengthen the framework for private investment and growth and reduce market uncertainty.

'The authorities' overall fiscal policy stance as outlined in the 2003 budget is appropriate. The authorities aim to maintain a sound tax base and be mindful of revenue slippages. To this end, they are prepared to take contingency measures in case of shortfalls in the 2003 budgetary revenues.

"The authorities' efforts to improve flscal transparency and accountability will also help to better track poverty-related expenditures financed by HIPC resources. Improvements in the treasury accounting system and the production of monthly economic and financial fiscal accounts beginning next year would reinforce the efforts already made," Mr. Aninat said. 


\section{Statement by Damian Ondo Mañe, Executive Director for the \\ Islamic Republic of Mauritania \\ December 4, 2002}

My Mauritanian authorities would like to thank the Managing Director for his recent visit to their country, and for the strong interest that he has shown in their adjustment efforts. My authorities would like to reiterate their strong determination to move forward with the reform agenda, to continue the fight against poverty, and to maintain the close relationship with the Fund.

Mauritania has continued to make good progress in the implementation of sound economic policies, and has concluded successfully the three-year arrangement under the PRGF. Significant progress has also been made in the execution of the Poverty Reduction Strategy. Program implementation in 2002 was in line with the program targets, except for the performance criterion on the publication of the 2001 financial audits of the central bank. The audit was published later than programmed, due to delay in the submission of the report by the auditors. My authorities are requesting a waiver for the non-observance of this performance criterion.

Macroeconomic performance remains satisfactory, although real GDP for 2002 has been revised downward due to lower mining production, a decline in fish catch, and unusually cold rains that killed more than 100,000 heads of catt]e. The fiscal account benefited from improved tax collections and the receipt of both the 2001 and 2002 fishing license payments by the European Union, and is expected to register a surplus of about 6.3 percent of GDP(excluding grants). The external current account, excluding transfers, is also expected to show a surplus of 1.2 percent of GDP in 2002, partly due to lower service payments. Although the ouguiya depreciated against the euro and the dollar, inflation remained subdued.

The authorities have continued with the implementation of the structural reform program, including the modernization of the customs department. Progress has also been made in the implementation of measures to reduce poverty. Significant improvement was achieved in those indicators that were not fully reached at completion point, namely, the child vaccination program, and school enrollment.

My authorities are convinced of the approach they are following, and are also fully committed to pursue steadfastly the adjustment process, which can help Mauritania overcome the challenges that it faces. In the pursuit of their efforts to improve social indicators and to strengthen macroeconomic performance, my authorities would like to continue to avail themselves of Fund's assistance under a new PRGF program which will also help to consolidate and maintain financial discipline, in particular, in view of upcoming elections. Their interest in such a program is also motivated by the recent discovery of important oil reserves. The revenue from the oil resources can give an important boost to the ongoing efforts to improve infrastructure, build needed capacity, reduce poverty, and improve the quality of life of the Mauritanians. My authorities are relying on the advice of the Fund to help them design the best way to manage these new resources which will come on stream in 2005. 
In the context of such a program, the authorities have prepared the 2003 Budget, and developed a program of structural reform, after close consultation with the staff. The program will have three main objectives, namely improving growth prospects, reducing poverty, and maintaining macroeconomic stability. The policies envisaged which will include an increase in social and poverty-related spending, should help to achieve real growth of over 5 percent, an inflation rate under 4 percent, and a fiscal deficit, equivalent to 2.3 percent of GDP. The policies in place should also help improve the external position.

In the fiscal area, the authorities project for 2003 an overall deficit, excluding grants, of about 2.3 percent of GDP. Revenue is projected at over 29 percent of GDP. While total expenditure is budgeted at 31.6 percent of GDP, it should be noted that current outlays will absorb only about 19 percent of GDP with capital outlays absorbing almost 12 percent. Social spending from HIPC resources will also see an increase to about 12 percent of GDP. The authorities have also proceeded with the simplification and streamlining of the payroll tax. From 11 rates, it has been reduced to 2 . The authorities expect the change to make an important contribution to poverty reduction. However, to compensate for the possibility of a loss in revenue in 2003 , the authorities will raise some fees and the sale price of government land.

In the pursuit of their efforts to encourage the development of the private sector, the authorities have for the second consecutive year reduced the corporate tax. The tax rate is being lowered from 25 to 20 percent. It should be noted that following the reduction last year, the yield from this tax improved. Moreover, the CNPM (employers' union) have committed themselves to abide fully by their obligations. Therefore, while noting the views of the staff on this issue, the authorities do not think that this measure will have an adverse impact on the Budget. In any case, they stand ready to take compensatory measures, should there be a revenue shortfall. The efforts to improve public expenditure management will be pursued, and the authorities are giving a high priority to the preparation of the monthly government financial and economic accounts.

As regards monetary policy, the authorities have maintained a prudent stance that have helped to keep inflation low, despite the depreciation of the currency. The authorities will follow closely inflationary developments and will tighten policies, if needed. The authorities have also started to implement the safeguards assessment, but work on the restructuring of the central bank has been slowed, pending a decision from the World Bank on the approach to take. My authorities remain fully committed to this objective and will start implementing the measures as soon as an agreement is reached with the World Bank.

On debt relief under the enhanced HIPC Initiative, the authorities are making good progress in their negotiations with creditors to secure debt relief. To improve monitoring of external debt, a new unit has been created at the central bank. The authorities have also agreed to introduce the action plans as recommend by the staff to strengthen the unit.

On the national social security fund (CNSS), the authorities agree with the staff that it needs to be restructured. They have received the final report from the ILO experts and have set up a technical committee in charge of analyzing and drafting an action plan that will be submitted soon to the interministerial committee in charge of overseeing the reform of the 
CNSS. The authorities remain fully committed to the implementation of measures that will help to reverse the difficult financial situation of the CNSS.

On the exchange rate, the foreign exchange market does not seem to be functioning efficiently, and the spread between the official rate and the parallel rate increased earlier in the year. This increase is more a reflection of the behavior of commercial banks than any policy change of the central bank. There are traditional and close links between banks and traders, especially the importers, such that the banks have generally favored these importers in the supply of foreign exchange. In order to ensure the availability of foreign exchange on the market, the authorities took two measures. The first one set limits on the transportation of foreign bank notes and regulates its handling up to a certain level; the other measure was to request fish exporters to surrender their export proceeds to the central bank which would then sell 70 percent, and deposit the remaining 30 percent in foreign currency in the exporters' bank accounts.

While the authorities understand the concerns of the staff regarding the latter measure, they would like to note that the objective was to alleviate the difficulties of economic agents to acquire foreign exchange, and to reduce the spread between the official and the parallel markets. In any case, the authorities view this measure as temporary and intend to review it. In the meantime, they have taken a number of additional measures aimed at increasing the transparency of the foreign exchange market. These include a publicity campaign to improve the public's awareness of its rights and obligations regarding access to foreign exchange and to explain the working of the market, and the request to banks to inform the central banks regarding their customers' requests for foreign exchange. It is to be noted that these measures were taken following a meeting with all interested parties, with Fund staff also present. In response to these measures, and the more active participation of the central bank in the market, the rates have stabilized, with the spread returning to its more normal 4 to 5 percent. The central bank will continue to monitor the situation carefully, and will take additional steps, if necessary.

An important source of rigidity in the Mauritanian economy has been the lack of institutions, infrastructure and capacity. The authorities will increase their efforts to strengthen these areas, in the coming years, through a wide ranging program of capacity -building. In pursuit of these efforts, they would like to receive further technical assistance from the Fund, especially through AFRITAC. This assistance will also be helpful in improving, among others, the foreign exchange market, and in contributing to attract foreign direct assistance. The authorities are well aware of the vulnerability of some sources of government revenue, and would like, with Fund's assistance, to continue the efforts to expand the taxable base, as well as creating the conditions for the development of a strong private sector, that will be the main source of employment.

In conclusion, my Mauritanian authorities would like to convey their appreciation to management and staff for the strong support they have received in the implementation of successive Fund programs, and which have enabled them to reach successfully the completion point under the enhanced HIPC Initiative, last May. As noted in the staff report and also in previous ones, significant progress has been achieved under Fund-supported program, and the Mauritanian economy is now in a better position to address the economic and financial 
challenges that it faces. Both internal and external balances have been stabilized, and growth prospects have improved significantly. Major structural reforms have already been undertaken or are underway. Nevertheless, further reforms are needed to put the economy on a solid growth path. In this context, my authorities would like to embark on a new medium-term program that place strong emphasis on the identification and development of sources of private sector-led growth, and on measures aimed at diversifying the economy. They also view such a successor program as helping them to set strong growth foundations, and to help them develop an exit strategy from the PRGF. 